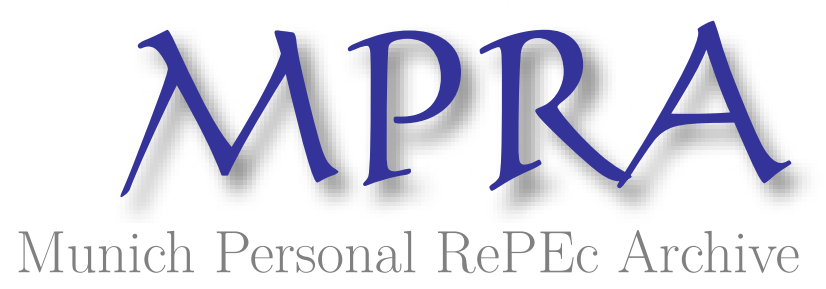

\title{
Does Distance Affect the Performance of Foreign Banks? Evidence from Multinational Banking in Developing Countries
}

\author{
Wu, Ji and Jeon, Bang Nam and Luca, Alina C. \\ Penn State Harrisburg, Drexel University, International Monetary \\ Fund
}

1 July 2010

Online at https://mpra.ub.uni-muenchen.de/37083/

MPRA Paper No. 37083, posted 04 Mar 2012 19:59 UTC 


\title{
Does Distance Affect the Performance of Foreign Banks? Evidence from Multinational Banking in Developing Countries
}

\author{
Ji Wu \\ Penn State University at Harrisburg \\ Bang Nam Jeon* \\ Drexel University, Philadelphia, PA \\ Alina C. Luca \\ International Monetary Fund, Washington, D.C.
}

\begin{abstract}
This paper examines whether the geographic distance between subsidiaries of multinational banks and their headquarters is an important factor in determining the performance of the subsidiaries. Using various performance indicators of 340 subsidiaries in 54 emerging and developing economies from 69 global banks during the years 1994-2008, we find evidence that first, the distance constraint adversely affects loan growth, profitability and performance of foreign bank subsidiaries, and second, the unfavorable information asymmetry faced by foreign banks, due to the distance constraint, in financing foreign clients cannot be fully overcome by establishing their presence abroad such as setting up their foreign subsidiaries. We further examine if the effect of distance is symmetric across different banks and countries, and find the following various economic, financial and institutional factors to affect the strength of distance constraints in the multinational banking activities: the entry mode of foreign banks, the history of presence in local markets, the existence of credit information institutions, the cultural similarity between the home and host markets, financial depth, financial crisis periods, the stock market development, the banking market structure in host markets, and the hierarchy of the subsidiary in the multinational banking conglomerate.
\end{abstract}

JEL code: $\mathrm{F} 34, \mathrm{G} 14, \mathrm{G} 21$

Keywords: Multinational banking, distance, information asymmetry, foreign bank penetration

\footnotetext{
* Corresponding author. Professor of Economics and International Business, Bennett S. LeBow College of Business, Drexel University, Philadelphia PA 19104, U.S.A. Tel: (215) 895-2125, E-mail:

jeonbana@drexel.edu. The views expressed herein are those of the authors and should not be attributed to the IMF, its Executive Board, or its management. We thank Suk-Joong Kim, the Guest Editor of the Journal, for very useful suggestions.
} 


\section{INTRODUCTION}

This paper examines the economic implications of distance in the realm of multinational banking, particularly the effect of the geographical distance between foreign bank subsidiaries and their headquarters on the performance of the foreign bank subsidiaries in emerging and developing countries. In the gravity model literature of international trade, it has been intensively studied and supported by numerous empirical studies that, after controlling for other factors, the exporter-importer distance imposes an important adverse effect on the bilateral trade links. In international finance, there have been several studies examining how the cross-border lending and portfolio investment activities are affected by geographical distance. For example, empirical papers, such as Portes et al. (2001), Portes and Rey (2005) and Buch (2005), found evidence that a longer distance in international banking have an adverse effect on cross-border lending or foreign asset holding, which is ascribed to higher informational costs as distance increases.

Banks depend on information to identify good borrowers and determine their loan supply. Credible information is especially essential to provide larger loans (Degryse and Ongena (2005)). However, banks' access to information (or ability to assess information) varies, thus affecting banks' performance. Compared to domestic banks, foreign banks especially face more adverse information constraints when they provide cross-border credit, since they might be thousands miles away from their customers. The constraints faced by foreign banks include higher costs to either identify potentially good borrowers or monitor borrowers. Banks can only obtain less precise information for more distant loan applicants (e.g. Almanza (2002), Hauswald and Marquez (2006) and Carling and Lundberg (2007)). The information disadvantages become more conspicuous and challenging in multinational banking operations.

Since the early 1990s, multinational banks have established a large number of subsidiaries outside their border. Foreign ownership in the banking system has increased significantly in a number of emerging economies. For example, as of end-2007, the share of foreign bank assets in banking sector total assets has reached 80 percent in Mexico, and exceeded the 90 percent level in several Central and Eastern European countries, such as Estonia, Romania, and the Czech Republic. (See BIS 2009, p.85) If a longer distance between the lender and the borrower really captures an adverse effect of information asymmetry associated with screening and monitoring, it is natural to ask if this "distance constraint" will stay the same or lose its edge when cross-border credit is substituted with local claims. In other words, we ask whether or not foreign banks are able to fully overcome the constraints of information asymmetry by shortening the geographical distance to customers through the establishment of their affiliates in borrowers' country. In the extant 
literature, however, only very few studies have examined if distance still plays any significant role in determining foreign banks' performance in terms of lending, pricing and their profits in host markets. To our best knowledge, our study is the first to examine a role of distance in multinational banking using bank-level data of headquarters and their foreign subsidiaries and the geographical and cultural distance between the two.

This paper addresses how the distance constraints faced by foreign banks affect their banking performance, and examines under what conditions the distance constraints may be alleviated or amplified. We specifically study whether and how foreign banks' performance is affected by the distance between the host market where subsidiaries are located and the home market where their headquarters are located. Note that, in the research at the domestic level, distance is conventionally defined as the closeness between a loan officer and his borrowers (for example, Peterson and Rajan (2002)). The definition of distance and its implications in our paper are very different one from this conventional one. Although foreign banks can substitute crossborder claims by local claims, it is far from certain that information barriers could be removed fully by a closer domestic vicinity to clients. Compared with domestic peers, foreign banks still likely face disadvantages in collecting information (especially "soft information" ${ }^{\text {) }}$ ) and identifying prime borrowers. As a result, foreign banks may still incur higher informational costs in their operation than domestic banks. The informational problem may disappear only after foreign banks have acquired the same pool of information as domestic banks, through many years of interaction with their clients in local markets.

Following Mian (2006), "distance constraints" in our paper reflect the extent of the difficulties with which foreign banks can overcome disadvantages of asymmetric information in host markets, caused by distance from their headquarters in the home country. Since a farther distance in multinational banking reflects a higher level of difficulty to know their clients and markets, one would expect that the negative effect of distance on the banking performance tends to be stronger for more distant foreign banks. How distance may constrain foreign banks' activities, if any, have important policy implications for countries which liberalize their financial sectors by allowing more foreign banks to enter the host banking markets.

Our paper extends the extant literature in the following directions: First, using a new data set of distance between multinational bank subsidiaries and their headquarters at the individual bank level, we examine the impact of distance constraints to international banking operations. If multinational banks could overcome the informational barriers by setting up local presence, the distance between host and home markets would be insignificant in determining their banking 
performance. Otherwise, a negative association between distance and banking performance can be explained as consistent evidence that foreign banks are still at the disadvantages of information asymmetry. Second, we focus our analysis on foreign banks in emerging and developing economies, where economic growth is pursued by opening up their financial sectors, as a result, witnessing an increase in the foreign bank presence. Since we use the samples from more than fifty emerging and developing countries, our results are more representative for developing countries in general. Third, we identify what are the specific amplifying or mitigating factors for the impact of distance in the multinational banking. These factors range from some characteristics of foreign bank subsidiaries, its hierarchical level in the conglomerate, the entry mode of foreign banks, and certain macroeconomic and financial conditions of the host countries.

The main findings of this paper can be summarized as follows: First, we find evidence that distance constraints, in deed, adversely affect the performance of foreign banks. This finding suggests that foreign banks cannot fully overcome information asymmetry simply by establishing a local presence in the host banking market. As the distance from their headquarters increases, a foreign bank tends to lend its loans only at a lower growth rate. A longer distance also impedes foreign banks to obtain higher profit, which may reduce their capacity and incentive to supply credit over a long run. Corresponding to their lower growth rate of loans and profits, foreign banks also increase the share of non-lending assets in their portfolio, leading to inefficiency in capital allocation. Second, although in general a longer distance negatively affects foreign banks' performance, its effect is not symmetric. The following factors are found to be able to alleviate the strength of distance constraints: the entry of foreign banks through the mergers and acquisitions (M\&A) mode, a longer history of presence in host markets, the existence of credit information institutions, the same language and region of host and home countries, higher financial deepening of host banking markets and highly developed stock market, a higher concentration level in the host banking market, and a higher hierarchy in its conglomerate. We also find that the effect of distance constraints becomes strong during crises than tranquil periods. Our results provide some useful policy implications for policy-makers in the host country of multinational banking.

The rest of the paper is organized as follows. Section 2 reviews relevant literature. Section 3 introduces the regression model. Section 4 describes our dataset, and Section 5 reports the benchmark results. Section 6 examines various factors that may alleviate or aggravate the effects of distance constraints in multinational banking. Section 7 concludes. 


\section{LITERATURE REVIEW: DISTANCE IN MULTINATIONAL BANKING}

In general, the availability and quality of information on borrowers play an important role in determining banks' credit (Stiglitz and Weiss (1981)). When banks have more accurate information about their borrowers, they tend to lend more loans. Pagano and Jappelli (1993) argue that the information exchange among banks enables them to find good borrowers and may increase their lending. Jappelli and Pagano (2002) and Djankov et al. (2007) show that the countries in which lenders exchange information through credit information sharing institutions (public credit registries or private credit bureaus) are associated with a higher ratio of credit to GDP. Brown et al. (2009) find that information sharing improves the availability of loans at lower costs to firms, especially for opaque firms. In addition to increasing the volume of loans, improved information availability also affects banks' performance by reducing debtors' default rates (Klein (1992), Vercammen (1995), Padilla and Pagano (2000)), increases the competition in banking markets and hence lowering interest rates (Pagano and Jappelli (1993), Padilla and Pagano (1997)), and reduces firms' incentive to over-borrow from multiple banks (Bennardo et al. (2008)).

Banks are believed to have different abilities to collect and assess borrowers' information. For example, large banks may be able to take the advantage of economies of scale from large information technology networks and hence are better at assessing "hard information". By contrast, small banks may be better at collecting and assessing "soft information" through loan officers by personal interactions. Stein (2002) suggests that large, hierarchical banks would have comparative disadvantages in assessing soft information relative to small banks. Consistent with his argument, Cole et al. (1999) show that large banks tend to employ standard criteria obtained from financial statements in the loan decision process, but small banks deviate from these criteria by relying to a larger extent on the soft information such as the character of the borrower. Moreover, young banks may be less effective to distinguish good borrowers from bad ones because of their short history of presence and less often interaction with potential clients. Archaya et al. (2002) find that a bank's monitoring effectiveness is dampened when the bank expand to newly-entered industries.

Distance is a practically useful proxy for the difficulties to acquire and communicate information, especially soft information (Hauswald and Marquez (2000), Berger et al. (2001), Petersen and Rajan (2002), Mian (2006), and Agarwal and Hauswald (2007)). A longer distance between banks and borrowers would make information collection and monitoring more costly and then deters banks from providing more loans, especially the relationship loans which depend 
more on local knowledge and personnel contacts. Almanza (2002) suggests that the resources spent by banks on monitoring increases with the distance between the bank and its debtors. He also finds that banks with higher capital are more willing to lend to distant borrowers.

How distance affects the price of loans could be ambiguous. On one hand, more distant borrowers would cost banks more resources to assess and monitor, hence banks would pass on this cost into the interest rate on loans. On the other hand, banks would extract rents from closer borrowers by charging higher rates since otherwise the borrowers would have to switch to more distant competing banks and pay higher interest rates. Degryse and Ongena (2005) find that loan interest rates tend to decrease with the distance between firms and lenders and increase with the distance between the firm and competing banks. The reason is explained as that more distant banks have only weaker market power and hence will charge borrowers lower interest rates. Agarwal and Hauswald (2007) find results in line with Degryse and Ongena (2005), and suggest the physical distance between bank and borrowers is actually a proxy for bank's different degree of information asymmetry. Mistrulli and Casolaro (2008) find that the interest rates on loans are negatively correlated with the distance between the bank headquarters and the borrower.

Huaswald and Marquez (2006) derive a negative relationship between loan rates and the distance of borrowers to relationship banks, but a positive relationship between the rates and the distance to transactional banks.

In other research (e.g. Berger and DeYoung (2001)), distance is also used as a proxy for the agency problem when a subsidiary is located far away from senior managers, hence with an increasing distance to the final decision makers, the subsidiaries may have less lending and lower profit efficiency. This strand of argument is consistent with Stein (2002). There is substantial evidence that information asymmetry would cause biases in the investment of market participants, for example, the literature on the well known "home bias" in assets holding (e.g. French and Poterba (1991), Gehrig (1993), Tesar and Werner (1995), Kang and Stulz (1997), Lewis (1999), Coval and Moskowitz (1999, 2001)). Portes and Rey (2005) provide an excellent survey on the literature of this issue.

It is only recent when a few empirical studies investigate the effects of distance on determining various specific types of international financial transactions. Most of these works find that distance is an important determinant of cross-border assets holding or international bank flows. Applying the gravity model methodology, Portes et al. (2001) and Portes and Rey (2005) show that geographical distance is negatively associated with the volume of international financial assets transactions, and the result is explained by a positive correlation between 
information friction and distance. Buch (2005) finds consistent evidence that banks hold significantly lower assets in distant foreign markets, and the importance of distance for holding assets abroad has not declined in European countries with technological progress over time. He also finds that distance constraints have not changed in its impact on cross-border asset holdings by the multinational banking sector over time during the period 1983-1999. Papaioannou (2005) also uses geographical distance to proxy the transaction and information costs, and find it is inversely associated with the cross-border bank flows. Herrero and Martinez Peria (2007) find that the informational costs significantly affect the share of local claims (to total claims) of foreign banks. Carey and Nini (2007) find that banks display home bias by providing more syndicated loans to their domestic borrowers than to foreign ones.

Siregar and Choy (2009) studies the determinants of the loans from international banks from OECD countries to East Asian countries, and find a negative relationship between the sourcerecipient geographical proximity and the amount of loans. Similar results are also found in Wei and $\mathrm{Wu}$ (2001), although they do not specifically address the relationship between distance and cross-border bank lending. It is worthwhile to note that, although there is overwhelming evidence that a farther distance between source and recipient countries would negatively affect investors or banks' decision to obtain foreign assets, there is likely a positive effect as well. The correlation of business cycle may likely decline in distance, hence a financial investment in remote countries might reward investors a higher return by portfolio diversification. If this is the case, the distance between source and recipient countries may be found positively related with international capital flows. Nevertheless, the extant empirical evidence seemingly suggests that this positive effect is practically dominated by the negative effects from information asymmetry.

However, research is still scant on the effect of distance from their headquarters on the performance of foreign bank subsidiaries which are located in host markets. If the geographical distance captures most of the information barriers between a lender and its continents-away borrowers, we expect that the distance constraints would not play any significant role if lenders could successfully know about their borrowers by setting up a local presence and narrowing the vicinity to their borrowers. So far, only a few papers have addressed the effects of the host-home market distance on foreign banks' local claims in the host country. Berger et al. (2001) find that for small business in Argentina, foreign banks headquartered in South America tend to provide more credit than foreign banks headquartered in other continents. Mian (2006) examines the credit from foreign banks in Pakistan, and finds that a greater cultural and geographic distance between the headquarters and their local branches prevents foreign banks to lend to 
informationally opaque but fundamentally sound firms. Claessens and van Horsen (2009) find that foreign banks from a home country geographically or culturally close to the host country perform better than distant foreign banks. ${ }^{2}$

The interpretation of distance constraints as information asymmetry has been supported in the literature. Several studies have also presented evidence that foreign banks may only serve the sectors which are less subject to information asymmetry. Clarke et al. (1999) observe the banking sector in Argentina and find that foreign banks concentrate their business in the industries that are less information asymmetric. Martinez Peria and Mody (2004) find that in the case of Latin American banks de novo foreign banks charge lower spreads than mergers \& acquisitions foreign banks, and interpret that de novo foreign banks with less information on the host banking markets has to focus on the most transparent sector, which are more likely competitive sectors. Accordingly, de novo foreign banks have to charge lower spreads than M\&A foreign banks. The results from these two works are consistent with the suggestion made by Dell'Ariccia and Marquez (2004) that foreign banks will enter the sectors where their information disadvantages are smaller.

\section{MODEL}

We set up the empirical model to examine how the distance from their headquarters affects the performance of foreign bank subsidiaries in host markets. is the banking performance is measured using four dimensions: (1) the growth rate of loans (in real terms); (2) the price charged by banks, represented by net interest margin; (3) the holding of non-lending assets, measured by the share of "other earning assets" to total bank assets; and (4) the profits of banks, proxied by the return on equity (ROE). We find that these four dimensions only modestly correlated. (Table A1) We use the following benchmark model for the estimation of the role of distance constraints to the banking performance of foreign bank subsidiaries:

$$
\begin{aligned}
Y_{i, j, k, l, t}= & c+\alpha \cdot \text { distance }_{j, l}+\beta \cdot(\text { bank characteristics })_{i, t}+\delta \cdot(\text { host characteristics })_{j, t} \\
& +\lambda \cdot(\text { parent characteristics })_{k, t}+\gamma \cdot(\text { home characteristics })_{l, t}+\varepsilon_{i, j, k, l, t}
\end{aligned}
$$

where the dependent variable $Y_{i, j, k, l, t}$ represents the banking performance of foreign bank subsidiary $i$ of conglomerate $k$ of the home country $l$ in host country $j$ in year $t$. distance $e_{j, l}$ is the geographical proximity between the host country $j$ and the home country $l$. (bank 
characteristics $)_{i, t}$ is a vector of subsidiary $i$ 's bank characteristics, including its liquidity, capitalization, size and riskiness. (host characteristics) ${ }_{j, t}$ is a vector of macroeconomic variables in host market $j$, including the growth rate of real GDP, the change in unemployment rate, foreign exchange depreciation rate (against US dollar), and a dummy of (expansionary) monetary policy with the value of 1 for an easy monetary policy and the value of 0 otherwise. (parent characteristics $)_{k, t}$ includes the financial strength of the parent bank $k$, such as the mass of the conglomerate, liquidity and capitalization. (home characteristics) $)_{l, t}$ represents the macroeconomic conditions in the home country $l$, including the growth rate of real GDP, the change in unemployment rate and a dummy of monetary policy. $\varepsilon_{i, j, k, l, t}$ is the idiosyncratic error. $\alpha, \beta, \delta, \lambda$ and $\gamma$ are the coefficients to be estimated.

Among the coefficients which we will estimate, $\alpha$ is of special interest, which is expected to reflect the sensitivity of foreign bank subsidiaries' performance to the distance constraints that they face. Distance is calculated as the geodesic distance between the geographic centers of the host and the home countries by applying Vincenty formula. We take logarithms for distance, since the marginal effect of the distance constraints may diminish as distance increases. If foreign banks are subject to higher informational costs in their operation, it is expected that a longer distance would be associated with a lower growth rate in loans. In addition, if the distance constraint hinders foreign banks to find good business opportunities, we should expect that they have to hold more non-lending assets, like deposits in other banks, securities, bonds and government treasury bills; hence the share of other earning assets to total assets will be increasing with the distance. Foreign subsidiaries' higher holding of non-lending assets, compared to lending assets, suggests a less efficient allocation of scarce financial resources in multinational banking.

How would the distance constraint affect the interest rate charged by foreign banks? The answer is not straightforward. On one hand, if a longer distance captures a higher cost to identify and monitor borrowers (or monitor managers), foreign banks may pass on this cost and charge a higher interest rate. On the other hand, a longer distance would cause less information about the host market and potential prime borrowers. This will drive foreign banks to concentrate their lending in more transparent industries which are more likely competitive than other opaque industries, and force banks to charge only a lower interest rate. Therefore, it seems how distance would affect interest rate is left as an empirical question. If a longer distance creates the informational disadvantage for foreign banks, we may reasonably expect that profits would decrease as distance increases. 
Following the standard practice, we include bank characteristics of foreign subsidiaries in the explanatory variable set to control for various types of financial constraints on the subsidiaries. It is likely that a longer distance from the headquarters actually represents a weaker financial strength of the subsidiary, especially when the conglomerate establishes a "weaker" (say, smaller, less liquid or less capitalized) subsidiary in a distant overseas market. This possibility can be controlled by including the subsidiary-level bank characteristics in the explanatory variable set. The correlation of distance and subsidiary characteristics are reported in Table A2, which indicates that the correlations are very mild in magnitude. Another argument that may arise is that a more distant foreign bank may have a lower growth rate of loans because of a lower demand from the host market. To control for the demand effect at the bank level and the macroeconomy level, we add a riskiness measure at the individual bank level and host country macroeconomic variables. The former, measured by the ratio of loan loss provision to total loans of a subsidiary controls for the heterogeneity across subsidiary banks' clients, while the latter controls for the heterogeneous demand factors across host countries. The variables of "bank characteristics" and "host characteristics" are the "pull factors" in determining the behavior of foreign banks.

The liquidity of banks is measured by the ratio of liquid assets to total assets. A more liquid bank tends to increase its credit more quickly. The capitalization of banks is proxied by the ratio of equity over total assets. A better capitalized bank is expected to have faster growing in its loans. The size of an individual bank measures the dominance of the bank in the host banking sector. The relative size of a bank is obtained by using the ratio of the total loans of the bank to the total domestic credit in the host economy. The riskiness faced by an individual bank is measured by the ratio of loan loss provision to total loans for a bank. In order to address the possible endogeneity problem of subsidiaries' characteristic variables in our model, we use one-year lagged values for those variables.

"Parent characteristics" and "home characteristics" are included to control for the "push factors" of foreign banks' performance in host markets. The former controls for the effects of the financial strength of the conglomerate on the subsidiaries' behavior, ${ }^{3}$ while the latter controls for the force that may lead the parent banks to seek external lending (via the oversea subsidiaries) ${ }^{4}$. The liquidity and capitalization of the conglomerates are measured in the same way for those for subsidiaries. The mass of a parent bank is proxied by the logarithm of its total assets in term of U.S. dollars. The correlation between distance and parent bank characteristics are reported in Table A3. The correlation between distance and parent bank mass is relative large (around 0.50), probably indicating that a large multinational bank can expand their foreign subsidiary network 
farther than a small multinational bank. We present evidence shortly that after controlling for the effect of conglomerate mass, distance is still a significant determinant of banks' performance.

In order to test whether the effect of distance constraints is symmetric across banks and host markets and to identify specific amplifying or mitigating factors for the strength of the distance constraints, we extend the benchmark model by adding interaction terms:

$$
\begin{aligned}
& Y_{i, j, k, l, t}=c+\alpha \cdot \text { distance }_{j, l}+\rho \cdot \text { factor }+\sigma \cdot\left(\text { factor } \times \text { distance }_{j, l}\right)+\beta \cdot(\text { bank characteristics })_{i, t} \\
& +\delta \cdot(\text { host characteristics })_{j, t}+\lambda \cdot(\text { parent characteristics })_{k, t}+\gamma \cdot(\text { home characteristics })_{l, t}+\varepsilon_{i, j, k, l, t}
\end{aligned}
$$

where factor represents an examined factor that may alleviate (or multiply) the effect of distance, and factor $\times$ distance $_{j, l}$ is its interaction term with distance. We examine various factors including: (1) the entry mode of foreign banks (de novo or M\&As); (2) the length of presence in host markets; (3) the existence of credit information institutions; (4) the same languages, legal systems, and relegion in the host and home countries; (5) the level of financial deepening in the host banking market; (6) the level of development of stock market; (7) the degree of concentration in the host banking market, and (8) the hierarchy level of the subsidiary in its conglomerate. More detailed discussion on each of the above factors will be made when we discuss the empirical results in Section 6. A summary of all variables and their data sources is provided in Table 1.

For the estimation, we apply the feasible generalized least squares (FGLS) estimator, which allows for the AR(1) autocorrelation within banks and heteroskedasticity across banks. We introduce country dummies and time-fixed effects in the estimation to control for other unaccounted sources of the differences in the bank performance across countries and years.

\section{DATA}

We construct unbalanced panel dataset for the estimation by using bank-level annual observations of balance sheet and income statements retrieved from Bureau van Dijk's BankScope database. Our data cover 340 foreign subsidiaries of 69 multinational banks from 1994 to 2008. All selected multinational banks are universally regarded as large banks with total assets of more than $\$ 521$ billion on average. ${ }^{5}$ We include only commercial bank subsidiaries in our dataset to reduce the possible bias due to the different nature and business scope of various non-commercial banks. We focus our analysis on the foreign subsidiaries of multinational banks located in a total of 54 emerging and developing countries. The list of selected multinational 
banks and the distribution of their subsidiaries in the interested countries is provided in Appendix Table A4.

A bank is defined as a foreign subsidiary if at least $50 \%$ of the entity's assets are owned by a multinational bank which is headquartered in another country. ${ }^{6} \mathrm{We}$ take the following steps to track the affiliation of a subsidiary to its parent bank over the period of 1994-2008. First, we check the subsidiary information of selected multinational banks recorded in BankScope, which identifies the ownership for some banks in the most recent year of recording. Second, we check the global presence of parent banks and their chronological history from their websites to pin down the establishment of their subsidiaries in foreign countries. Third, we review the profile of each individual subsidiary bank and its historical evolution from its website. In most cases, it is highlighted in the bank's profile about its incorporation and changes of its ownership. Fourth, we depend on another comprehensive database, SDC Platinum, which records detailed information on mergers and acquisitions. We collect data on when a bank in the host country was acquired by or merged into the conglomerate of the parent bank in the home country. Finally, if we are still unable to identify the ownership of the bank after going through these four steps, we resort to various other information sources, such as banks' annual reports, central bank publications, and Internet news reports on changes in the bank ownership and affiliation.

We use unconsolidated data for subsidiaries in principle and consolidated data are used only when unconsolidated data are not available for that bank. In our dataset, only $6 \%$ of observations are consolidated for subsidiaries. For parent banks, by contrast, we use consolidated data to reflect the state of the conglomerate instead of the only holding company. Since all selected subsidiaries are small compositions (in terms of their assets) in the conglomerate, using consolidated data for the parent bank would not cause serious problem of endogeneity ${ }^{7}$.

We drop the outliers by applying the following steps: First we remove the observations if the subsidiaries' annual growth rate of total assets exceeds 300\%, which could be the result of mergers and acquisitions in the host country; second, we drop the data if the growth rate of loans is higher than $400 \%$, which could occur in the early years of the subsidiaries or in the financial turmoil; third, we delete the observations when subsidiaries' riskiness is larger than $100 \%$ or lower than $-100 \%$. We lose quite a number of banks from the removal of the outliers and the usage of one-year lags for subsidiary characteristics variables, but still have around 250 bank observations for our regression.

We collect macroeconomic variables from International Financial Statistics (IFS). We resort to various sources to collect data for the factors that may affect the effects of distance 
constraints. These variables and their sources are represented in Table 1, and will be further explained in Section 6.

\section{BENCHMARK RESULTS: DOES DISTANCE MATTER FOR THE PERFORMANCE OF FOREIGN BANK SUBSIDIARIES?}

We first estimate the equation (1) and examine whether the distance between the host and the home markets plays an important role for the performance of foreign bank subsidiaries located in the host countries. The results are reported in Table 2.

First of all, after controlling for all other factors affecting the bank performance, we find distance is still an important determinant of banks' behavior. The coefficient on the variable distance is negative and statistically significant in all regressions. A more distant foreign subsidiary is shown to supply loans at only a lower growth rate. This finding is consistent with the literature of "information asymmetry" in that higher informational costs to identify and monitor borrowers would discourage banks from providing more credit. Consistent with the findings in Petersen and Rajan (2002), Degryse and Ongena (2005) and Agarwal and Hauswald (2007), distance is found negatively correlated with net interest margin, implying that a foreign bank from a more distant home country charge borrowers lower interest rates. The reason can be that a distant foreign bank is characterized with more disadvantageous informational possession and consequently only lower market power, which prevents them from charging higher interest rates to borrowers. Another explanation is that a more distant foreign subsidiary will be forced to specialize only in the most transparent industries. These industries are more likely to be competitive and hence banks have to charge only lower interest rates.

Since distant foreign banks own less information to find good business opportunities, they may have to hold more non-lending assets such as deposits in other banks, securities, bonds and treasury bills. This conjecture is supported by the positive coefficient of distance in the regression of the share of other earning assets. Finally, distance is negatively associated with return on equity, which suggests that a more distant foreign bank be less profitable than other closer foreign banks. It is worthwhile to note that our results are essentially consistent with the insights of "gravity model". Multinational banks tend to allocate their loans to more proximate clients, as represented as the "home bias" proposition in that they hold financial assets issued by closer (or domestic) debtors over-proportionately.

Our finding suggests that information asymmetry cannot be completely overcome by establishing a local presence of multinational banks in the host country. As Mian (2006) pointed 
out using the case of the Pakistani banking, one of the policy implications is that foreign bank participation in developing countries may face a significant challenge in advancing their financial development by attracting multinational banks from abroad. Since foreign banks are constrained by the asymmetric information, they may not be interested in serving some firms (for example, the opaque small firms), which would negatively impact the economic growth in host countries. A higher holding of non-lending assets by foreign banks may also result in a less efficient allocation of scarce financial resources. Moreover, since a higher information barrier lowers foreign banks' profitability, it may undermine their incentive and capability to provide long-term credit. A pool of financially healthy domestic banks equipped with better capacity for collecting soft information for loan would compensate the disadvantage of foreign banks in assessing information and work as a necessary complement in developing host banking markets.

We also find some other interesting results. For example, it is shown that higher liquidity enables banks to increase credit at a higher growth rate and charge a lower interest spread, which is consistent with prior works like Kashyap and Stein (2000) and Gambacorta (2005, 2008). Capitalization is positively associated with net interest margin. This finding is consistent with Demirguc-Kunt and Huizinga (1998), who find that higher-capitalized banks tend to get the lower cost for funding. Larger and more risky banks tend to provide more stable credit, but charge higher interest rate and possess a higher ratio of non-loan assets. Host macroeconomic conditions affect banks' loans as well. The coefficient on the growth rate of real GDP is positive and statistically significant, suggesting a higher economic growth stimulate higher demand for bank credit. The coefficient on the change in unemployment rate is negative, implying that aggregate demand and hence the demand for credit would decrease when labor market is tight.

When the host central bank conducts an expansionary monetary policy, banks significantly lend more credit at lower interest margin than when monetary policy turns tightened. Banks increase their lending when domestic currency is depreciated, probably because values for foreign banks' assets denominated in local currency increase, and at the same time increase interest spread, which reflects uncovered interest parity when foreign currencies are relatively strengthened. We also find the financial strength of parent banks affect subsidiaries' lending. Banks from a large and highly liquid conglomerate increase loans at a lower rate. The result that subsidiaries' performance is affected by the financial strength of their parent banks is in line with the literature of "internal capital market" like Gilbert (1991), Houston et al. (1997), and De Haas and van Lelyveld (2009). We find weak evidence that home countries macroeconomic variables 
affect subsidiaries' behavior, hence foreign banks are not found to import fluctuations into host countries.

\section{FURTHER RESULTS: WHAT FACTORS MODIFY THE EFFECT OF DISTANCE CONSTRAINTS?}

We next test if the adverse effect of distance on bank performance is symmetric across banks and countries, or put differently, if there is any factor that may buffer or amplify the impact of distance. We do that by adding the tested factor and also its interaction with distance. A significant coefficient on the interaction term can be translated as the factor would affect banks' performance through changing the effects of distance. ${ }^{8}$

\subsection{Entry mode}

Foreign banks can set up overseas subsidiaries through either de novo establishment or mergers $\&$ acquisitions (M\&A). Rather than gathering the information of markets and potential borrowers from scratch, a foreign bank established through the M\&A entry can inherit the pool of information from its predecessor, hence largely overcome the barrier of information asymmetry. We test the effect of entry mode on the distance constraints by introducing the interaction term distance $\times$ dummy $(M \& A)$, where dummy $(M \& A)$ has a value of 1 if the foreign subsidiary is built through acquiring a local bank, and it has a value of 0 if the foreign subsidiary is built though de novo establishment.

The results are reported in Table 3 . We find the coefficient on distance $\times$ dummy $(M \& A)$ is positive and statistically significant in the regressions of the loan growth rate and net interest margin, but insignificant in the share of other earning assets and return on equity. These results indicate that a foreign bank entered through the M\&A mode is less constrained by asymmetric information than a de novo foreign bank in providing loans and setting interest rates.

Van Tassel and Vishwasrao (2007) argue that foreign banks choose an M\&A entry mode in order to capture the information endowment of domestic banks. Lehner (2009) suggests that foreign banks with superior screening technology would prefer an M\&A entry to a greenfield entry. On the other hand, Martinez Peria and Mody (2004) find that de novo foreign banks charge lower spreads than mergers \& acquisitions foreign banks in the Latin American banking sector. They interpret the findings that de novo foreign banks possess only the least information about the host markets and thus need to focus on the most transparent sectors, which are more likely competitive sectors. Accordingly, de novo foreign banks have to charge lower spreads than M\&A 
foreign banks. Our finding that foreign subsidiaries entered through an M\&A mode are less

affected by distance than those entered through a de novo mode is consistent with the arguments that foreign subsidiaries entered through M\&As have better information on the host banking market than those entered through greenfields, and are able to charge lower loan rates.

\subsection{History of presence}

Foreign banks can accumulate information about host markets and their clients in the process of their operations; hence controlling for all else, a foreign bank which has already been operating in the market for years would possess a richer pool of information than a bank newly entered. We collect the data on banks' history from their profiles and BankScope, and use the number of years of operation in the host markets as the history of presence variable. For foreign banks that were established by M\&A, its length of history started back to the date when the acquired bank was built. The effect of length of history is detected by adding the interaction term distance $\times$ history, and the results are reported in Table 4 .

As expected, the interaction distance $\times$ history is positive and statistically significant in regressions of the loan growth rate and net interest margin, and negative in the share of other earning assets. A foreign bank with a longer operation history in the host market is shown to be less affected by distance, and accordingly lends more loans, sets higher interest margin and holds less non-loan assets. These results are consistent with our conjecture that "senior" banks know the market better than their "junior" counterparts.

\subsection{Information institutions}

Credit information institutions can help banks to have better access to the information on potential borrowers and overcome the adverse selection caused by information asymmetry. Djankov et al. (2007) find evidence that the existence of credit information institutions boosts more private credit in their sample of 129 countries. Brown et al. (2009) find that the information sharing provided by credit information institutions improves the availability and lower cost of credit, especially to opaque firms.

In practice, credit information institutions include public credit registries and private credit bureaus. Good examples of the former institutions include databases managed by a government agency (usually the central bank) that collects information on the standing of borrowers in the financial market and make it available to actual and potential lenders. The latter institutions include private firms or non-profit organizations that maintain databases on the standing of borrowers to facilitate information exchange among banks and other financial institutions. We 
construct three dummy variables--dummy (information institution), dummy (public credit registry) and dummy (private credit bureau)--to capture, respectively, the existence of either public credit registries or private credit bureaus, public credit registries only, or private credit bureaus only. The main data source for the credit information institutions, public and private, is the World Bank Doing Business database.

First, we only include dummy (information institution) and its interaction with distance in regression (Table 4. panel A). We find the existence of the information institutions dampens the adverse effects of distance on the loan growth rate and net interest margin. A same distant foreign bank located in a host country with either a public credit registry or a private credit bureau provide more loan and can charge higher interest spread than its counterparts in host countries without credit information institutions. Next, we test the separate effects of public credit registry and private bureau in affecting the role of distance constraints. We add both dummy (public credit registry) and dummy (private credit bureau) and their interactions with distance in regression (Table 4. panel B). We find both types of information institutions contribute to lowering the effects of distance on the loan growth rate and the interest spread. Public credit registry may also help foreign subsidiaries to hold less non-lending assets. These results are consistent with the idea that foreign banks can retrieve information from credit information institutions and use them in evaluating the loan applications. Our findings suggest that the construction of credit information institutions seems to be a valuable component for the policy of financial liberalization in developing countries.

\subsection{Language, legal system and region}

Intuitively, if a multinational bank expands its subsidiaries into a host market which is culturally more similar to its own home market, it may incur lower informational costs. In order to test the proposition, we use three dimensions to measure the cultural similarity between host and home countries: the (same) language and legal system in the host and home countries, and the (same) region where host and home countries are located. ${ }^{9}$ In the extant literature, the impact, on multinational banking, of whether the borrower and the bank are located in the same region as a proxy of the cultural distance have been examined (see Mian (2006) and Claessens and van Horen (2009).) However, the examination that whether these national features can weaken or aggravate the negative effects of distance on foreign subsidiaries behavior is still scant. We construct three dummy variables, dummy (same language), dummy (same legal system) and dummy (same region), to capture, respectively, if the host and home countries have the same 
official languages, the same legal origins, and are geographically in the same region. ${ }^{10}$ The main data sources are CIA World Factbook and La Porta et al. (1998).

We add these three dummies and their interaction with distance respectively in regressions. The results are reported in Table 6. The coefficient on dummy (same language) is statistically significant in the regressions of the loan growth rate and the share of other earning assets, supporting the idea that the same language used in both host and home countries reduces the effects of distance in credit provision and assets allocation. This result implies that foreign banks would possess and communicate more precise information about their clients by avoiding extra costs from inter-lingual translation. The coefficient on dummy (same region) is statistically significant and shows an expected sign in determining net interest margin and ROE. That is, compared to its same distant counterparts, a foreign bank can own more market power, charge higher interest margin, and earn higher profits if its headquarters is located in the same region of the host market. However, the coefficient on dummy (same legal system) is not statistically significant in any regression, providing little evidence that same legal systems may strengthen or dampen the impact of distance constraints. ${ }^{11}$

\subsection{Financial deepening}

Banks and other financial institutions arise to ameliorate the problems created by asymmetric information; hence the information of potential borrowers will be more transparent in a more developed financial market. We test if foreign banks face less severe or more strict distance constraints when they are operating in financially more developed host markets.

The degree of financial development is measured using the ratio of private credit by depository banks to GDP, which are collected from the financial structure database provided by Beck (2009). The results are reported in Table 7. We find that the coefficient on the interaction term of distance with host financial deepening is statistically significant in determining the growth of loans, net interest margin and ROE, suggesting that a higher financial development plays a buffering role to the adverse effects of distance. In a host country with higher financial depth, a foreign bank increases its credit at higher growth rate, have a larger interest spread and hence higher profits, compare to other distant foreign banks. Our finding implies that, as the host financial sector develops, foreign banks would encounter declining information asymmetry and provide more financing in host countries.

Why foreign banks are subject to less adverse distance constraints in a more developed banking market? One explanation is that, financial depth also reflects the dependence of firms on 
banks to finance their investment. The more firms are dependent on banks, the more actively they provide verifiable evidence for their creditworthiness, hence the less adverse the informational asymmetry is.

\subsection{Crisis}

Banks may encounter worse informational problem when the economy falls in crisis, which can greatly deteriorate firms' operation outcomes and obscure their business prospects. Mishkin (1990) describes the nature of financial crisis as a disruption of markets in which the asymmetric information problems of adverse selection and moral hazard become much worse. We test whether or not crises would deteriorate the effects of distance constraints.

A dummy veriable, dummy (financial crisis), is constructed equal to 1 if the host country experiences a systematic banking crisis, using the data in Caprio and Klingebiel (2003) and Laeven and Valencia (2008). The results are reported in Table 8.

The coefficient on the interaction term distance $\times$ dummy (financial crisis) is found negative and statistically significant in regressions of loan growth and net interest margin, which is consistent with our expectation that information asymmetry becomes deteriorated during crisis periods. Given the same distance, foreign banks in host crises are more hesitant to expand their credit, and have only narrowed the interest spread. To avoid confusion, note that our result does not contradict with the conventional observations that in crisis banks charge higher interest rate to borrowers. The individual term dummy (financial crisis) is shown to have a positive and statistically significant coefficient, indicating that interest rates are higher during the crisis periods. However, a negative and statistically significant coefficient on distance $\times$ dummy (financial crisis) only suggests that the adverse effect of distance on interest spread is strengthened by crises, probably because the increase in the loan interest rate is offset by an increase in the cost of funding.

\subsection{Stock markets}

The development of stock market may influence the capacity of collecting information on borrowers by banks. The intuition is that a more developed stock market will have firms' financial information more transparent and easier to access by banks, especially for those publicly listed companies. In this section, we test how the stock market development influences the effects of distance on foreign banks' performance.

We use three variables to measure the development in stock market: namely, number of listed companies as the share of listed companies divided by total population in host countries, 
stock market capitalization as the value of listed shares divided by GDP, and stock market turnover rate as the ratio of the value of total shares traded to market capitalization. We collect the data from the structure database provided by Beck (2009). We add these three variables and their interactions with distance in our regressions. The results are reported in Table 9.

We find the coefficient on number of listed companies is statistically significant in all regressions and show the expected sign, supporting a proposition that an increase in the number of listed companies improves the informational problem (Table 9 panel A). Given same distance as its peers, a foreign bank subsidiary in a host country where there are more publicly listed companies tends to provide more lending, be able to charge higher interest rates, hold less nonlending assets, and earn higher profits. The coefficients on stock market capitalization is positive in regressions of loan growth and net interest margin (Table 9 panel B), while the coefficient on stock market turnover rate is statistically significant in regressions of loan growth and the share of other earning assets (Table 9 panel C). Both results are in line with the proposition that foreign banks incur lower informational costs in the host country where stock markets are well developed.

Our results also shed some light on the specialization of foreign banks in serving domestic clients. Since publicly listed companies are usually large companies in an economy, the finding that the effects of informational problem on foreign banks' behaviors can be improved by the development of stock market suggests that foreign banks may lend more credit to large companies, and may exclude small firms whose information is limited because the financial information on those firms are not publically available in stock markets.

\subsection{Concentration}

The dependence of banks on the quality of information on borrowers may be affected by the competition level in the financial market. Empirical evidence on this proposition is still far from conclusive. (See Archaya et al. (2002), Boot and Thakor (2002), Huaswald and Marquez (2006), Mistrulli and Casolaro (2008) and Zarutski (2008))

We test the effects of competition on how distance influence foreign subsidiaries' lending. We use the level of banking concentration as a proxy for the competition in host banking markets. It is widely accepted that the more concentrated the banking sector is, the less competitive it is. Concentration is defined as the share of total assets owned by the largest three banks in total assets of banking sector. The data is selected from the financial structure database provided by Beck (2009). 
The results are reported in Table 10. The coefficient on the interaction variable, distance $\times$ concentration, is found to be positive and statistically significant in regressions for loan growth rate and interest rate, and negative in regression for the share of other earning assets. These results suggest that the adverse distance effects are less pronounced in a more concentrated (less competitive) banking sector. A same distant foreign subsidiary tends to increase its loans at a higher rate, charges higher interest rate, and holds less non-loan assets in a more concentrated market. Archaya et al. (2002) argue that a bank's monitoring effectiveness is dampened when the bank expand to more competitive sectors, results in lower quality of loans. Huaswald and Marquez (2006) suggest that banks tend to decrease their investment to acquire borrowers' information when competition is intensified. Our results are in line with this finding.

\subsection{Hierarchy}

Stein (2002) shows that loan officers in hierarchically complex conglomerates will have a lower incentive to collect information about borrowers. This is because they do not generally have decision making authority, and instead they have to report that information to their supervisors. Based on this argument, we may expect that, a subsidiary with higher hierarchy in the conglomerate will be less separate from the ultimate decision makers, more likely influence CEO's decisions, and hence have stronger incentive to identify potential prime borrowers. Therefore, a subsidiary with a higher hierarchy might be less affected by the distance constraint than a peer with a lower hierarchy.

We use the relative size of bank assets of the subsidiary in the conglomerate to proxy its hierarchy, that is, the ratio of the subsidiary's total assets to the total assets of the conglomerate. When a subsidiary manages more assets in the conglomerate, it implies that it is standing on a higher hierarchy.

The results are reported in Table 11. The coefficient on the interaction term, distance $\times$ hierarchy, shows an expected sign and is statistically significant in all bank performance dimensions. Compared to same distant peers, a higher hierarchical subsidiary tends to provide more loans, charge higher interest rate, hold less other earning assets, and earn higher profits. These results suggest that a higher standing in the conglomerate may help banks less constrained by information asymmetries. This provides consistent evidence that the managers of higher hierarchical subsidiaries have stronger incentive and capacity to collect the information on borrowers, and implies that parent banks may "export" their superior expertise to higher hierarchical subsidiaries than lower ones. (Berger and De Young (2001) and Stein (2002)) 


\subsection{Robustness tests}

It can be reasonably argued that the above-discussed factors may be correlated to each other and hence they actually capture something alike. In this section we test the robustness of our finding by add all significant factors in regression. For instance, we exclude the insignificant factors and add only dummy (M\&A), history, dummy (information institutions), dummy (same language), host financial deepening, dummy (financial crisis), number of listed companies, stock market capitalization, stock market turnover rate, concentration and hierarchy and their interaction with distance into the regression of the loan growth rate.

The results are reported in Table 12. To no surprise, some factors lose their significance since multicollinearity can be hardly avoided in this regression. Even though we cannot simply rule out the importance of those variables just because they are not statistically significant in these augmented regressions, we find stronger evidence for some factors since their significance remains. It is confirmed that there are many factors which mitigate or multiply the role of distance constraints in the loan performance of foreign subsidiaries in multinational banking. They include the loan growth rate, the history of presence, the existence of credit information institutions, the same language in host and home markets, and the financial development. For net interest margin, we find robust support for the force of the history of presence, the same region where host and home countries are located, and the financial development level. For the share of other earning assets, the history of presence, the same language, the turnover rate in stock market, and the hierarchy hold on their significance. For ROE, all added factors are shown to be statistically significant, namely, the same region, the financial development, the number of listed companies and the hierarchy of the subsidiary.

We also conduct a robustness test to check if there have been any systematic shifts over years in the role of distance constraints on the performance of foreign subsidiary banks.

According to the estimation results, we are not able to get statistically significant evidence for the system shift over time in our sample observations. This finding is consistent with Bush (2005) which reports that the importance of distance for the foreign assets holdings of banks has not changed for commercial banks from G-5 countries doing business in 50 host countries for the period 1983-1999. However, we expect that the role of distance on the performance of foreign banks in the emerging and developing host countries diminishes over the long run due to the advancement of information technology, communication infrastructure, and globalization of the banking industry. 


\section{Conclusion}

This paper addresses the significance of the host-home distance in affecting the performance of foreign subsidiaries in host country markets. Our results suggest that, first, the distance constraint adversely affects loan growth, profitability and performance of foreign bank subsidiaries, and second, the unfavorable information asymmetry faced by foreign banks, due to the distance constraint, in financing foreign clients cannot be smoothed out simply by establishing their presence abroad such as setting up their foreign subsidiaries. Foreign banks still need to have years of operation to learn the markets and accumulate more precise information pool for potential borrowers.

The effect of distance is not symmetric across banks and countries. We identify various factors, affecting the role of distance in multinational banking. They are associated with bank characteristics (entry mode and history of presence), national features (existence of credit information institutions, cultural similarity with home countries, financial development, crises, stock market development, and the level banking market concentration) and the conglomerate structure (hierarchy). We find evidence that they play an effective role in determining the strength of distance on foreign subsidiaries' behavior and performance. Our results imply that, given the same distance from their home markets and other controlled variables, foreign banks would show heterogeneity in their performance, depending on where they are located.

Our findings in this paper have some important policy implications. A policy that discourages mergers \& acquisitions of foreign banks to domestic banks but encourage de novo establishment may produce less optimal outcome, since de novo foreign banks face more adverse distance constraints and information asymmetry in identifying their potential clients. Entry permission is shown not to be sufficient for good performance of foreign banks in host markets. The governments in host countries need to proactively establish and develop credit information institutions as a complement of the financial liberalization policy. Another important policy implication is that the policy-makers in developing countries should not ignore the financial health and development of domestic banks, since foreign banks are subject to the informational problem and may cause inefficient allocation of scarce financial resources in the host countries. The financial development cannot be achieved only by allowing the entry of foreign banks. A pool of strong domestic banks, with informational advantages, can compensate the disadvantage of foreign banks with distance constraints and information asymmetry, and act as an indispensible participant in the financial markets. 


\section{References}

Agarwal, Sumit and R. Hauswald, 2007, "Distance and Information Asymmetries in Lending Decisions,"

Federal Researve Bank of Chicago Proceedings, Iss. May, pp. 183-204.

Almanza, Andres, 2002, “A Model of Competition in Banking: Bank Capital vs Expertise," Journal of

Financial Intermediation, Vol. 11, pp. 87-121.

Archaya, Viral, I. Hasan, and A. Saunders, 2002, "The Effects of Focus and Diversification on Bank Risk and Return: Evidence from Individual Bank Loan Portfolios,” BIS Working Paper No. 118.

Ashcraft, Adam, 2008, "Are Bank Holding Companies a Source of Strength to Their Banking

Subsidiaries?" Journal of Money, Credit and Banking, Vol. 40, pp. 273-294.

Bank for International Settlement (BIS), 2009, "Capital Flows and Emerging Market Economies," CGFS Papers No. 33, January.

Beck, Thorsten, A. Demirguc-Kunt and R. Levine, 2003, "Law and Finance: Why Does Legal Origin Matter," Journal of Comparative Economics, Vol. 31, Iss. 4, pp. 653-675.

Beck, Thorsten, A. Demirguc-Kunt, and R. Levine, 1998, "A New Database on Financial Development and Structure," World Bank Policy Research Working Paper 2146.

Beck, Thorsten and A. Demirguc-Kunt, 2009, "Financial Institutions and Markets across Countries and over Time - Data and Analysis," World Bank Working Paper.

Bennardo, Alberto, M. Pagano and S. Piccolo, 2008, "Multiple-Bank Lending, Creditor Rights and Information Sharing," CSEF Working Paper 211.

Berger, Allen and R. DeYoung, 2001, "The Effects of Geographic Expansion on Bank Efficiency," Journal of Financial Services Research, Vol. 19, Iss. 2, pp 163-184.

Berger, Allen, L. Klapper and G. Uddell, 2001, "The Ability of Banks to Lend Informationally Opaque Small Business," Journal of Banking and Finance, Vol. 25, pp. 2127-2167.

Boot, Arnoud and A. Thakor, 2002, "Can Relationship Banking Survive Competition?" Journal of Finance, Vol. 55, Iss. 2, pp. $679-713$.

Brown, Martin, T. Jappelli and M. Pagano, 2009, "Information Sharing and Credit: Firm-Level Evidence from Transition Countries," Journal of Financial Intermediation, Vol. 18, Iss. 2, pp. 151-172.

Buch, Claudia, 2005, "Distance and International Banking," Review of International Economics, Vol. 13, Iss. 4 , pp. 787-804.

Carling, Kenneth and S. Lundberg, 2005, “Asymmetric Information and Distance: An Empirical Assessment of Geographical Credit Rationing," Journal of Economics and Business, Vol. 57, Iss. 1, pp. 3959.

Campello, Murillo, 2002, "Internal Capital Markets in Financial Conglomerates: Evidence from Small Bank Responses to Monetary Policy," Journal of Finance, Vol. 57, No. 6, pp. 2773-2805.

Caprio, Gerard and D. Klingebiel, 2003, "Episodes of Systematic and Borderline Financial Crises," World Bank Research Working Paper.

Carey, Mark and G. Nini, 2007, "Is the Corporate Loan Market Globally Integrated? A Pricing Puzzle," Journal of Finance, Vol. 62, Iss. 6, pp. 2969-3007. 
Coval, Joshua and T. Moskowitz, 1999, "Home Bias at Home: Local Equity Preference in Domestic Portfolios,” Journal of Finance, Vol. 54, Iss. 6, pp. 2045-2073.

Coval, Joshua and T. Moskowitz, 2001, "The Geography of Investment: Informed Trading and Asset Prices," Journal of Political Economy, Vol. 109, Iss. 4, pp. 811-841.

Claessens, Stijn, N. van Horsen, T. Gurcanlar and J. Mercado, 2008, "Foreign Bank Presence in Developing Countries 1995 - 2006: Data and Trends," Working Paper.

Claessens, Stijn and N. van Horsen, 2009, "Being a Foreigner among Domestic Banks: Asset or Liability," MPRA Paper No. 13467.

Clarke, Geroge, R. Cull, L. D' Amato and A. Molinari, 1999, “The Effect of Foreign Entry on Argentina's Domestic Banking Sector,” World Bank Policy Research Working Paper 2158.

Cole, Rebel, L. Goldberg and L. White, 1999, "Cookie-Cutter vs Character: The Micro Structure of Small Business Lending by Large and Small Banks" Federal Reserve Bank of Chicago, Proceedings, Iss. May, pp 362-389.

De Haas, Ralph and I. van Lelyveld, 2010, "Internal Capital Markets and Lending by Multinational Bank Subsidiaries," Journal of Financial Intermediation, Vol. 19, pp. 1-25.

Degryse, Hans and S. Ongena, 2005, "Distance, Lending Relationships and Competition," Journal of Finance, Vol. 60, Iss. 1, pp 231-266.

Dell'Ariccia, Giovanni and R. Marquez, 2004, “Information and Bank Credit Allocation," Journal of Financial Economics, Vol. 72, pp 185-214.

Demirguc-Kunt, Asli and H. Huizinga, 1998, "Determinants of Commercial Bank Interest Margins and Profitability: Some International Evidence,” World Bank Policy Research Working Paper No. 1900.

Djankov, Simeon, C. McLiesh and A. Shleifer, 2007, "Private Credit in 129 Countries," Journal of Financial Economics, Vol. 84, Iss. 2, pp 299-329.

French, Kenneth and J. Poterba, 1991, "Investor Diversification and International Equity Markets," American Economic Review, Vol. 81, Iss. 2, pp 222-226.

Gambacorta, Leonardo, 2005, "Inside the Bank Lending Channel," European Economic Review, Vol. 49, Iss. 7, pp. 1737-1759.

Gambacorta, Leonardo, 2008, "How do Banks Set Interest Rates?" European Economic Review, Vol. 52, Iss. 5, pp. 792-819.

Gehrig, Thomas, 1993, “An Information Based Explanation of the Domestic Bias in International Equity Investment," Scandinavian Journal of Economics, Vol. 95, Iss. 1, pp. 97-109.

Gilbert, R. Alton, 1991, "Do Bank Holding Companies Act as "Sources of Strength" for Their Bank Subsidiaries," Economic Review, Federal Reserve Bank of St. Louis, January/February.

Goldberger, Linda, 2005, “The International Exposure of U.S. Banks,” NBER Working Paper, No. 11365.

Hauswald, Robert and R. Marquez, 2000, "Relationship Banking, Loan Specialization and Competition," Federal Reserve Bank of Chicago, Proceedings, May, pp. 108-131.

Hauswald, Robert and R. Marquez, 2006, "Competition and Strategic Information Acquisition in Credit Market," Review of Financial Studies, Vol. 19 (3), pp. 967-1000. 
Herrero, Alicia G. and M.S. Martinez Peria, 2007, “The Mix of International Banks' Foreign Claims:

Determinants and Implications," Journal of Banking and Finance, Vol. 31, pp 1613-1631.

Holod, Dmytro and Joe Peek, 2006, "Capital Constraints, Asymmetric Information and Internal Capital Markets in Banking: New Evidence," Working paper.

Houstan, Joel, C. James and D. Marcus, 1997, "Capital Market Frictions and the Role of Internal Capital Markets in Banking," Journal of Financial Economics, Vol. 46, pp. 135-164

Houston, Joel and C. James, 1998, “Do Bank Internal Capital Market Promote Lending?” Journal of Banking \& Finance, Vol. 22, pp. 899-918.

Jappelli, Tullio and M. Pagano, 2000, "Information Sharing in Credit Markets: A Survey," CSEF Working Paper 36.

Jappelli, Tullio and M. Pagano, 2002, "Information Sharing, Lending and Defaults: Cross-Country

Evidence," Journal of Banking and Finance, Vol. 26, Iss. 10, pp. 2017-2045.

Kang, Jun-Koo and R. Stulz, 1997, "Why is There a Home Bias? An Analysis of Foreign Portfolio Equity Ownership in Japan," Journal of Financial Economics, Vol. 46, Iss. 1, pp 3-28.

Kashyap, Anil and J. Stein, 2000, "What Do a Million Observations on Banks Say about the Transmission of Monetary Policy," American Economic Review, Vol. 90, Iss. 3, pp 407-428.

Klein, Daniel, 1992, "Promise Keeping in the Great Society: A Model of Credit Information Sharing," Economics and Politics, Vol. 4, No. 2, pp. 117-136.

La Porta, Rafael, F. Lopez-de-Silanes, A. Shleifer and R. Vishny, 1998, “Law and Finance,” Journal of Political Economy, Vol. 106, Iss. 6, pp. 1113-1155.

Laeven, Luc and F. Valencia, 2008, "Systematic Banking Crises: A New Database," IMF Working Paper $\mathrm{WP} / 08 / 224$.

Lehner, Maria, 2009, "Entry Mode Choice of Multinational Banks," Journal of Banking and Finance, Vol. 33, Iss. 10, pp. 1781-1792.

Lewis, Karen, 1999, "Trying to Explain Home Bias in Equities and Consumption," Journal of Economic Literature, Vol. 37, Iss. 2, pp 571-608.

Martinez Peria, Maria Soledad and A. Mody, 2004, "How Foreign Participation and Market Concentration Impact Bank Spreads: Evidence from Latin America," World Bank Policy Research Paper 3210.

Mian, Atif, 2006, "Distance Constraints: the Limits of Foreign Lending in Poor Economies," Journal of Finance, Vol. 61, Iss. 3, pp. 1465-1505.

Mishkin, Frederic, 1990, “Asymmetric Information and Financial Crises: A Historic Perspective,” NBER Working Paper No, 3400.

Mistrulli, Paolo E. and L. Casolaro, 2008, "Distance, Lending Technologies and Interest Rates,” Working Paper.

Padilla, A. J., and M. Pagano, 2000, "Sharing Default Information as a Borrower Discipline Device," European Economic Review, Vol. 44, pp. 1951-1980.

Padilla, A. J., and M. Pagano, 1997, "Endogenous Communication among Lenders and Entrepreneurial Incentives," Review of Financial Studies, Vol. 10, pp. 205-236. 
Pagano, Marco and T. Jappelli, 1993, "Information Sharing in Credit Markets," Journal of Finance, Vol. 48, Iss. 5, pp. 1693-1718.

Papaioannou, Elias, 2005, "What Drives International Bank Flows? Politics, Institutions and Other Determinants," European Central Bank Working Paper, No. 437.

Peek, Joe and E. Rosengren, 2000, "Collateral Damage: Effects of the Japanese Real Estate Collapse on Credit Availability and Real Activity in the United States," American Economic Review, Vol. 90, Iss. 1, pp. $30-45$.

Peterson, Mitchell and R. Rajan, 2002, "Does Distance Still Matter? The Information Revolution in Small Business Lending," Journal of Finance, Vol. 57, Iss. 6, pp. 2533-2570.

Portes, Richard, H. Rey and Y. Oh, 2001, "Information and Capital Flows: the Determinants of Transactions in Financial Assets," European Economic Review, Vol. 45, pp. 783-796.

Portes, Richard and H. Rey, 2005, “The Determinants of Cross-Border Equity Flows,” Journal of International Economics, Vol. 65, pp. 269-296.

Siregar, Reza Y. and K. M. Choy, 2009, "Determinants of International Bank Lending from Developed World to East Asia,” MPRA Working Paper, No. 14989.

Stein, Jeremy, 2002, "Information Production and Capital Allocation: Decentralized vs Hierarchical Firms," Journal of Finance, Vol. 57, pp. 1891-1921.

Stiglitz, Joseph and A. Weiss, 1981, "Credit Rationing in Markets with Imperfect Information," American Economic Review, Vol. 71, Iss. 3, pp. 393-410.

Tesar, Linda and I. Werner, 1995, "Home Bias and High Turnover," Journal of International Money and Finance, Vol. 14, Iss. 4, pp. 467-492.

Van Tassel, Eric and S. Vishwasrao, 2007, "Asymmetric Information and the Mode of Entry in Foreign Credit Markets," Journal of Banking and Finance, Vol. 31, Iss. 12, pp. 3742-3760.

Vercammen, James, 1995, "Credit Bureau Policy and Sustainable Reputation Effects in Credit Markets," Economica, Vol. 62, Iss. 248, pp. 461-478.

Wei, Shang-Yin and Y. Wu, 2001, "Negative Alchemy? Corruption, Composition of Capital Flow and Currency Crisis," NBER Working Paper, No. 8187.

Zarutskie, Rebecca, 2008, “Competition and Specialization in Credit Markets," Working Paper. 
Table 1: List of variables

\begin{tabular}{|c|c|c|c|c|c|}
\hline Variable & Description & Source & Mean & Std. dev. & Median \\
\hline Distance & $\begin{array}{l}\text { The logarithms of geodesic distance between the geographic centers of the } \\
\text { host and home countries (in } 1000 \text { kilometers). }\end{array}$ & $\begin{array}{l}\text { Authors' own calculation based } \\
\text { CIA World Factbook }\end{array}$ & 1.190 & 1.189 & 1.591 \\
\hline Loan growth rate & The annual growth rate of real loans (in \%). & BankScope & 23.533 & 54.209 & 14.157 \\
\hline Net interest margin & The ratio of net interest income to total earning assets of banks (in \%). & BankScope & 5.093 & 4.572 & 4.040 \\
\hline $\begin{array}{l}\text { Share of other } \\
\text { earning assets }\end{array}$ & The ratio of non-loans assets to total earning assets of banks (in \%). & BankScope & 42.282 & 23.657 & 39.927 \\
\hline ROE & Return on equity (in \%). & BankScope & 9.416 & 27.531 & 11.450 \\
\hline Liquidity & The ratio of liquid assets to total assets (in \%). & BankScope & 38.253 & 19.256 & 35.738 \\
\hline Capitalization & The ratio of equity to total assets (in \%). & BankScope & 13.237 & 10.038 & 10.368 \\
\hline Size & $\begin{array}{l}\text { Relative size of a bank in the banking sector, measured by the ratio of the } \\
\text { bank's loans to the banking sector total loans (in \%). }\end{array}$ & BankScope and IFS & 3.827 & 6.848 & 1.244 \\
\hline Riskiness & The ratio of loan loss provision to total loans (in \%). & BankScope & 1.897 & 5.031 & .835 \\
\hline $\begin{array}{l}\text { Host GDP growth } \\
\text { rate }\end{array}$ & The growth rate of real GDP in host countries (in \%). & IFS & 5.493 & 5.183 & 5.050 \\
\hline $\begin{array}{l}\text { Host change in } \\
\text { unemployment }\end{array}$ & First-order difference in unemployment rate in host countries (in \%). & IFS & -.125 & 1.460 & -.200 \\
\hline $\begin{array}{l}\text { Dummy (host } \\
\text { monetary policy) }\end{array}$ & $\begin{array}{l}\text { A dummy }=1 \text { if the host central bank conducts expansionary monetary } \\
\text { policy }=0 \text { otherwise. }\end{array}$ & IFS & .588 & .492 & 1 \\
\hline $\begin{array}{l}\text { Host depreciation } \\
\text { rate }\end{array}$ & Foreign exchange depreciation rate of host currency against U.S. dollar. & IFS & 3.810 & 23.415 & 0.000 \\
\hline Parent bank mass & $\begin{array}{l}\text { The logarithms of the total assets of the conglomerate (in billions of U.S. } \\
\text { dollar). }\end{array}$ & BankScope & 12.583 & 1.177 & 12.714 \\
\hline Parent bank liquidity & The ratio of liquid assets to total assets of the conglomerate (in \%). & BankScope & 28.023 & 12.793 & 26.678 \\
\hline $\begin{array}{l}\text { Parent bank } \\
\text { capitalization }\end{array}$ & The ratio of equity to total assets of the conglomerate (in \%). & BankScope & 5.459 & 2.432 & 5.049 \\
\hline $\begin{array}{l}\text { Home GDP growth } \\
\text { rate }\end{array}$ & The growth rate of real GDP in home countries (in \%). & IFS & 2.565 & 2.436 & 2.172 \\
\hline $\begin{array}{l}\text { Home change in } \\
\text { unemployment }\end{array}$ & First-order difference in unemployment rate in home countries (in \%). & IFS & -.290 & .891 & -.299 \\
\hline $\begin{array}{l}\text { Dummy (home } \\
\text { monetary policy) }\end{array}$ & $\begin{array}{l}\text { Dummy = } 1 \text { if the home central bank conducts expansionary monetary } \\
\text { policy = } 0 \text { otherwise. }\end{array}$ & IFS & .608 & .488 & 1 \\
\hline Dummy (M\&A) & $\begin{array}{l}\text { Dummy }=1 \text { if the foreign subsidiary is established by merger } \& \\
\text { acquisition }=0 \text { if established from scratch }\end{array}$ & $\begin{array}{l}\text { Banks' profile, SDC platinum, } \\
\text { annual reports, and etc }\end{array}$ & .438 & .496 & 0 \\
\hline
\end{tabular}


Dummy (information institution)

Dummy (same

language)

Dummy $=1$ if either a public credit registry or a private credit bureau exists in the host country $=0$ otherwise.

Dummy $=1$ if the host and home countries have the same official

language.

Dummy (same legal Dummy $=1$ if the host and home countries have the same legal system.

system)

Dummy (same

region)

Host financial

deepening

Dummy (financial

crisis)

Number of listed

companies in host

stock market

Stock market

capitalization

Stock market

turnover

Concentration

Hierarchy
Dummy $=1$ if the host and home countries are located in a same region.

Ratio of domestic credit to private sector to GDP (in \%).

Dummy $=1$ if the host market experienced a systematic banking crisis in given year

Number of publicly listed companies per $10 \mathrm{~K}$ population.

The ratio of stock market capitalization to GDP (in \%).

Stock market turnover ratio.

Assets of three largest banks as a share of assets of all commercial bank (in \%).

The ratio of the assets owned by the subsidiary to the total assets of the conglomerate (in \%). and etc

The World Bank "Doing

Business" database

CIA World Factbook

La Porta et al. (1998), CIA

World Factbook

CIA World Factbook

Financial Structure Database by Beck (2009)

Caprio and Klingebiel (2003)

Laeven and Valencia (2008)

Financial Structure Database by Beck (2009)

Financial Structure Database by Beck (2009)

Financial Structure Database by

Beck (2009)

Financial Structure Database by

Beck (2009)

BankScope

$\begin{array}{ccc}.870 & .336 & 1 \\ .162 & .368 & 0 \\ .471 & .499 & 0 \\ .433 & .495 & 0 \\ 39.577 & 29.825 & 29.019 \\ .268 & .443 & 0 \\ .254 & .456 & .060 \\ & & \\ 43.082 & 56.009 & 25.982 \\ 32.494 & 62.529 & 23.397 \\ 54.962 & 15.613 & 56.141 \\ 1.172 & 2.564 & .238\end{array}$


Table 2. Estimation results on the effects of distance on bank performance

\begin{tabular}{|c|c|c|c|c|}
\hline \multicolumn{5}{|l|}{ Dependent variables } \\
\hline & $\begin{array}{c}\text { Loan growth } \\
\text { rate }\end{array}$ & $\begin{array}{l}\text { Net interest } \\
\text { margin }\end{array}$ & $\begin{array}{l}\text { Share of other } \\
\text { earning assets }\end{array}$ & ROE \\
\hline Distance & $\begin{array}{c}-4.927 * * * \\
(1.296)\end{array}$ & $\begin{array}{l}-.210^{*} \\
(.114)\end{array}$ & $\begin{array}{c}1.224^{* *} \\
(.581)\end{array}$ & $\begin{array}{c}-1.224 * * \\
(.574)\end{array}$ \\
\hline Liquidity & $\begin{array}{c}.153 * * * \\
(.044)\end{array}$ & $\begin{array}{c}-.019 * * * \\
(.002)\end{array}$ & $\begin{array}{c}.593 * * * \\
(.018)\end{array}$ & $\begin{array}{l}.008 \\
(.017)\end{array}$ \\
\hline Capitalization & $\begin{array}{l}.124 \\
(.100)\end{array}$ & $\begin{array}{l}.024 * * * \\
(.006)\end{array}$ & $\begin{array}{l}.085 * * \\
(.035)\end{array}$ & $\begin{array}{c}-.137 * * * \\
(.031)\end{array}$ \\
\hline Size & $\begin{array}{c}-.404 * * * \\
(.122)\end{array}$ & $\begin{array}{c}.030 * * * \\
(.009)\end{array}$ & $\begin{array}{l}.094 * * \\
(.047)\end{array}$ & $\begin{array}{c}.369 * * * \\
(.062)\end{array}$ \\
\hline Riskiness & $\begin{array}{c}-.697 * * * \\
(.195)\end{array}$ & $\begin{array}{l}.037 * * * \\
(.011)\end{array}$ & $\begin{array}{l}.127^{*} \\
(.068)\end{array}$ & $\begin{array}{l}.081 \\
(.117)\end{array}$ \\
\hline Host GDP growth rate & $\begin{array}{c}1.213 * * * \\
(.169)\end{array}$ & $\begin{array}{c}-.032 * * * \\
(.008)\end{array}$ & $\begin{array}{c}-.143 * * \\
(.065)\end{array}$ & $\begin{array}{c}.381 * * * \\
(.074)\end{array}$ \\
\hline Host change in unemployment & $\begin{array}{l}-.787 * \\
(.424)\end{array}$ & $\begin{array}{l}-.042 \\
(.026)\end{array}$ & $\begin{array}{l}-.183 \\
(.156)\end{array}$ & $\begin{array}{c}.019 \\
(.186)\end{array}$ \\
\hline Dummy (host monetary policy) & $\begin{array}{c}5.642 * * * \\
(1.215)\end{array}$ & $\begin{array}{c}-.184 * * * * \\
(.062)\end{array}$ & $\begin{array}{l}.488 \\
(.438)\end{array}$ & $\begin{array}{l}-.278 \\
(.508)\end{array}$ \\
\hline Host depreciation rate & $\begin{array}{c}.085 * * * \\
(.027)\end{array}$ & $\begin{array}{l}.013 * * * \\
(.002)\end{array}$ & $\begin{array}{c}.001 \\
(.010)\end{array}$ & $\begin{array}{l}-.032 * * \\
(.016)\end{array}$ \\
\hline Parent bank mass & $\begin{array}{c}-1.732^{* * *} \\
(.837)\end{array}$ & $\begin{array}{l}-.031 \\
(.065)\end{array}$ & $\begin{array}{c}2.707 * * * * \\
(.315)\end{array}$ & $\begin{array}{c}1.347^{* * * *} \\
(.392)\end{array}$ \\
\hline Parent bank liquidity & $\begin{array}{c}-.190 * * * \\
(.066)\end{array}$ & $\begin{array}{c}-.015 * * * \\
(.004)\end{array}$ & $\begin{array}{c}.140 * * * \\
(.025)\end{array}$ & $\begin{array}{c}-.090 * * * \\
(.027)\end{array}$ \\
\hline Parent bank capitalization & $\begin{array}{l}-.036 \\
(.309)\end{array}$ & $\begin{array}{l}.099 * * * \\
(.026)\end{array}$ & $\begin{array}{l}-.048 \\
(.114)\end{array}$ & $\begin{array}{l}.134 \\
(.142)\end{array}$ \\
\hline Home GDP growth rate & $\begin{array}{l}-.323 \\
(.228)\end{array}$ & $\begin{array}{l}-.003 \\
(.018)\end{array}$ & $\begin{array}{l}.085 \\
(.103)\end{array}$ & $\begin{array}{l}-.312 * * \\
(.122)\end{array}$ \\
\hline Home change in unemployment & $\begin{array}{l}-.756 \\
(.675)\end{array}$ & $\begin{array}{c}.015 \\
(.040)\end{array}$ & $\begin{array}{l}-.196 \\
(.217)\end{array}$ & $\begin{array}{l}-.466^{*} \\
(.281)\end{array}$ \\
\hline Dummy (home monetary policy) & $\begin{array}{c}.569 \\
(1.868)\end{array}$ & $\begin{array}{l}.019 \\
(.088)\end{array}$ & $\begin{array}{l}.357 \\
(.690)\end{array}$ & $\begin{array}{c}.351 \\
(.799)\end{array}$ \\
\hline Year dummies & Yes & Yes & Yes & Yes \\
\hline Country dummies & Yes & Yes & Yes & Yes \\
\hline Observations (no. of banks) & $1307(254)$ & $1307(254)$ & $1301(253)$ & $1304(254)$ \\
\hline Goodness of fit & .183 & .368 & .693 & .150 \\
\hline
\end{tabular}

Notes: The numbers in parentheses denote errors of the coefficients. $* * * 1 \%$, ** 5\%, and * $10 \%$. 
Table 3. Estimation results on the effects of entry mode on distance constraints

\begin{tabular}{|c|c|c|c|c|}
\hline \multicolumn{5}{|l|}{ Dependent variables } \\
\hline & $\begin{array}{l}\text { Loan growth } \\
\text { rate }\end{array}$ & $\begin{array}{c}\text { Net interest } \\
\text { margin }\end{array}$ & $\begin{array}{l}\text { Share of other } \\
\text { earning assets }\end{array}$ & ROE \\
\hline Distance & $\begin{array}{c}-6.827 * * * \\
(1.379)\end{array}$ & $\begin{array}{c}-.192^{* *} \\
(.093)\end{array}$ & $\begin{array}{c}1.257^{* *} \\
(.617)\end{array}$ & $\begin{array}{l}-.962 \\
(.670)\end{array}$ \\
\hline Dummy (M\&A) & $\begin{array}{l}3.618 * \\
(2.048)\end{array}$ & $\begin{array}{l}.166 \\
(.118)\end{array}$ & $\begin{array}{l}.373 \\
(.814)\end{array}$ & $\begin{array}{l}-1.601 * \\
(.892)\end{array}$ \\
\hline Distance $\times$ Dummy $(M \& A)$ & $\begin{array}{c}2.574 * * \\
(1.151)\end{array}$ & $\begin{array}{l}.270 * * * \\
(.079)\end{array}$ & $\begin{array}{c}.096 \\
(.480)\end{array}$ & $\begin{array}{l}-.966 \\
(.608)\end{array}$ \\
\hline Other variables & Yes & Yes & Yes & Yes \\
\hline Year dummies & Yes & Yes & Yes & Yes \\
\hline Country dummies & Yes & Yes & Yes & Yes \\
\hline Observations (no. of banks) & $1307(254)$ & $1307(254)$ & $1301(253)$ & $1304(254)$ \\
\hline Goodness of fit & .190 & .280 & .695 & .147 \\
\hline
\end{tabular}

Notes: The numbers in parentheses denote errors of the coefficients. $* * * 1 \%$, ** 5\%, and * $10 \%$.

Table 4. The effects of history of presence on distance constraints

\begin{tabular}{|c|c|c|c|c|}
\hline \multicolumn{5}{|l|}{ Dependent variables } \\
\hline & $\begin{array}{c}\text { Loan growth } \\
\text { rate }\end{array}$ & $\begin{array}{c}\text { Net interest } \\
\text { margin }\end{array}$ & $\begin{array}{l}\text { Share of other } \\
\text { earning assets }\end{array}$ & ROE \\
\hline Distance & $\begin{array}{c}-12.459 * * * \\
(2.190)\end{array}$ & $\begin{array}{c}-.341^{* * *} \\
(.155)\end{array}$ & $\begin{array}{c}3.784 * * * \\
(.843)\end{array}$ & $\begin{array}{l}-.370 \\
(1.142)\end{array}$ \\
\hline History & $\begin{array}{l}-1.253 \\
(1.163)\end{array}$ & $\begin{array}{c}.320^{* * * *} \\
(.082)\end{array}$ & $\begin{array}{c}1.597 * * * \\
(.407)\end{array}$ & $\begin{array}{l}-.351 \\
(.595)\end{array}$ \\
\hline Distance $\times$ History & $\begin{array}{c}2.623 * * * * \\
(.622)\end{array}$ & $\begin{array}{l}.096 * * \\
(.046)\end{array}$ & $\begin{array}{c}-.949 * * * \\
(.218)\end{array}$ & $\begin{array}{l}-.276 \\
(.312)\end{array}$ \\
\hline Other variables & Yes & Yes & Yes & Yes \\
\hline Year dummies & Yes & Yes & Yes & Yes \\
\hline Country dummies & Yes & Yes & Yes & Yes \\
\hline Observations (no. of banks) & $1290(251)$ & $1290(251)$ & $1284(250)$ & $1287(251)$ \\
\hline Goodness of fit & .187 & .264 & .703 & .143 \\
\hline
\end{tabular}

Notes: The numbers in parentheses denote errors of the coefficients. $* * * 1 \%$, ** 5\%, and * $10 \%$. 
Table 5. Estimation results on the effects of credit information institutes on distance constraints

\begin{tabular}{|c|c|c|c|c|}
\hline \multicolumn{5}{|l|}{ "Dependent variables } \\
\hline & $\begin{array}{c}\text { Loan growth } \\
\text { rate }\end{array}$ & $\begin{array}{c}\text { Net interest } \\
\text { margin }\end{array}$ & $\begin{array}{l}\text { Share of other } \\
\text { earning assets }\end{array}$ & ROE \\
\hline \multicolumn{5}{|c|}{ Panel A: Public registry or private bureau } \\
\hline Distance & $\begin{array}{l}-10.242 * * * \\
(2.792)\end{array}$ & $\begin{array}{c}-.625^{* * * *} \\
(.125)\end{array}$ & $\begin{array}{l}1.206 \\
(.816)\end{array}$ & $\begin{array}{l}-.539 \\
(1.044)\end{array}$ \\
\hline Dummy (information institutes) & $\begin{array}{c}-5.369 * * \\
(2.611)\end{array}$ & $\begin{array}{c}-.316^{* *} \\
(.142)\end{array}$ & $\begin{array}{c}-3.121 * * * \\
(1.017)\end{array}$ & $\begin{array}{l}1.230 \\
(.950)\end{array}$ \\
\hline $\begin{array}{l}\text { Distance } \times \text { Dummy (information } \\
\text { institutes) }\end{array}$ & $\begin{array}{l}5.579 * * \\
(2.567)\end{array}$ & $\begin{array}{l}.319^{* * * *} \\
(.112)\end{array}$ & $\begin{array}{l}-.336 \\
(.794)\end{array}$ & $\begin{array}{l}-.946 \\
(.971)\end{array}$ \\
\hline Other variables & Yes & Yes & Yes & Yes \\
\hline Year dummies & Yes & Yes & Yes & Yes \\
\hline Country dummies & Yes & Yes & Yes & Yes \\
\hline Obs (no. of banks) & $1307(254)$ & $1307(254)$ & $1301(253)$ & $1304(254)$ \\
\hline Goodness of fit & .183 & .322 & .634 & .153 \\
\hline \multicolumn{5}{|c|}{ Panel B: Public registry and private bureau } \\
\hline Distance & $\begin{array}{c}-11.137 * * * \\
(1.994)\end{array}$ & $\begin{array}{c}-.656^{* * * *} \\
(.122)\end{array}$ & $\begin{array}{l}1.900^{* * *} \\
(.769)\end{array}$ & $\begin{array}{l}-.422 \\
(.940)\end{array}$ \\
\hline Dummy (public registry) & $\begin{array}{l}-2.986 \\
(4.235)\end{array}$ & $\begin{array}{l}.173 \\
(.172)\end{array}$ & $\begin{array}{c}.141 \\
(1.655)\end{array}$ & $\begin{array}{r}4.200 * * \\
(1.712)\end{array}$ \\
\hline Distance $\times$ Dummy (public registry) & $\begin{array}{r}3.965^{* *} \\
(1.721)\end{array}$ & $\begin{array}{l}.349 * * \\
(.167)\end{array}$ & $\begin{array}{l}-2.182 * * \\
(.863)\end{array}$ & $\begin{array}{r}-1.510 \\
(.971)\end{array}$ \\
\hline Dummy (private bureau) & $\begin{array}{l}-2.539 \\
(2.355)\end{array}$ & $\begin{array}{l}-.336 * * \\
(.144)\end{array}$ & $\begin{array}{c}-4.259 * * * \\
(1.109)\end{array}$ & $\begin{array}{c}.381 \\
(1.022)\end{array}$ \\
\hline Distance $\times$ Dummy (private bureau) & $\begin{array}{c}4.629 * * * \\
(1.584)\end{array}$ & $\begin{array}{l}.192 * \\
(.106)\end{array}$ & $\begin{array}{l}.045 \\
(.740)\end{array}$ & $\begin{array}{l}-.312 \\
(.807)\end{array}$ \\
\hline Other variables & Yes & Yes & Yes & Yes \\
\hline Year dummies & Yes & Yes & Yes & Yes \\
\hline Country dummies & Yes & Yes & Yes & Yes \\
\hline Obs (no. of banks) & $1307(254)$ & $1307(254)$ & $1301(253)$ & $1304(254)$ \\
\hline Goodness of fit & .164 & .329 & .635 & .143 \\
\hline
\end{tabular}

Note: The numbers in parentheses denote errors of the coefficients. $* * * 1 \%, * * 5 \%$ and $* 10 \%$. 
Table 6. Estimation results on the effects of language, legal system and region on distance constraints

\begin{tabular}{|c|c|c|c|c|}
\hline \multicolumn{5}{|l|}{ Dependent variables } \\
\hline & $\begin{array}{l}\text { Loan growth } \\
\text { rate }\end{array}$ & $\begin{array}{c}\text { Net interest } \\
\text { margin }\end{array}$ & $\begin{array}{l}\text { Share of other } \\
\text { earning assets }\end{array}$ & ROE \\
\hline \multicolumn{5}{|c|}{ Panel A: Same language } \\
\hline Distance & $\begin{array}{c}-7.944 * * * \\
(1.387)\end{array}$ & $\begin{array}{l}-.304 * * \\
(.123)\end{array}$ & $\begin{array}{c}1.378^{* *} \\
(.630)\end{array}$ & $\begin{array}{l}-1.659 * * \\
(.729)\end{array}$ \\
\hline Dummy (same language) & $\begin{array}{r}-12.349 \\
(9.121)\end{array}$ & $\begin{array}{c}1.697 * * \\
(.760)\end{array}$ & $\begin{array}{l}7.940 * * \\
(3.469)\end{array}$ & $\begin{array}{c}3.132 \\
(5.024)\end{array}$ \\
\hline Distance $\times$ Dummy (same language) & $\begin{array}{l}9.435^{* *} \\
(4.192)\end{array}$ & $\begin{array}{l}-.468 \\
(.324)\end{array}$ & $\begin{array}{l}-2.969 * \\
(1.613)\end{array}$ & $\begin{array}{l}1.016 \\
(2.087)\end{array}$ \\
\hline Other variables & Yes & Yes & Yes & Yes \\
\hline Year dummies & Yes & Yes & Yes & Yes \\
\hline Country dummies & Yes & Yes & Yes & Yes \\
\hline Obs (no. of banks) & $1307(254)$ & $1307(254)$ & $1301(253)$ & $1304(254)$ \\
\hline Goodness of fit & .179 & .370 & .689 & .155 \\
\hline \multicolumn{5}{|c|}{ Panel B: Same legal system } \\
\hline Distance & $\begin{array}{l}-5.058 * * * \\
(1.289)\end{array}$ & $\begin{array}{l}-.252 * \\
(.129)\end{array}$ & $\begin{array}{c}3.101^{* * * *} \\
(.514)\end{array}$ & $\begin{array}{c}-1.431 * * \\
(.670)\end{array}$ \\
\hline Dummy (same legal system) & $\begin{array}{c}1.233 \\
(1.696)\end{array}$ & $\begin{array}{c}-.444 * * * \\
(.141)\end{array}$ & $\begin{array}{l}-.255 \\
(.739)\end{array}$ & $\begin{array}{l}-.828 \\
(.820)\end{array}$ \\
\hline $\begin{array}{l}\text { Distance } \times \text { Dummy (same legal } \\
\text { system) }\end{array}$ & $\begin{array}{c}-.831 \\
(1.083)\end{array}$ & $\begin{array}{l}.076 \\
(.093)\end{array}$ & $\begin{array}{l}.236 \\
(.482)\end{array}$ & $\begin{array}{l}.035 \\
(.569)\end{array}$ \\
\hline Other variables & Yes & Yes & Yes & Yes \\
\hline Year dummies & Yes & Yes & Yes & Yes \\
\hline Country dummies & Yes & Yes & Yes & Yes \\
\hline Obs (no. of banks) & $1307(254)$ & $1307(254)$ & $1301(253)$ & $1304(254)$ \\
\hline Goodness of fit & .176 & .365 & .669 & .151 \\
\hline \multicolumn{5}{|c|}{ Panel C: Same region } \\
\hline Distance & $\begin{array}{c}-6.364 * * \\
(2.841)\end{array}$ & $\begin{array}{c}-1.064 * * * \\
(.266)\end{array}$ & $\begin{array}{c}.681 \\
(1.228)\end{array}$ & $\begin{array}{l}-4.414^{* *} \\
(2.166)\end{array}$ \\
\hline Dummy (same region) & $\begin{array}{l}-4.287 \\
(6.453)\end{array}$ & $\begin{array}{c}-1.631 * * * * \\
(.609)\end{array}$ & $\begin{array}{c}.682 \\
(2.749)\end{array}$ & $\begin{array}{l}-7.185 \\
(4.892)\end{array}$ \\
\hline Distance $\times$ Dummy (same region) & $\begin{array}{l}-3.726 \\
(3.393)\end{array}$ & $\begin{array}{c}1.206 * * * \\
(.296)\end{array}$ & $\begin{array}{l}-.587 \\
(1.513)\end{array}$ & $\begin{array}{l}4.326^{*} \\
(2.376)\end{array}$ \\
\hline Other variables & Yes & Yes & Yes & Yes \\
\hline Year dummies & Yes & Yes & Yes & Yes \\
\hline Country dummies & Yes & Yes & Yes & Yes \\
\hline Obs (no. of banks) & $1307(254)$ & $1307(254)$ & $1301(253)$ & $1304(254)$ \\
\hline Goodness of fit & .177 & .391 & .682 & .152 \\
\hline
\end{tabular}

Note: The numbers in parentheses denote errors of the coefficients. *** $1 \%$, ** 5\% and * $10 \%$. 
Table 7. Estimation results on the effects of financial deepening on distance constraints

\begin{tabular}{|c|c|c|c|c|}
\hline \multicolumn{5}{|l|}{ Dependent variables } \\
\hline & $\begin{array}{l}\text { Loan growth } \\
\text { rate }\end{array}$ & $\begin{array}{l}\text { Net interest } \\
\text { margin }\end{array}$ & $\begin{array}{l}\text { Share of other } \\
\text { earning assets }\end{array}$ & ROE \\
\hline Distance & $\begin{array}{c}-7.680 * * * \\
(1.903)\end{array}$ & $\begin{array}{c}-.964^{* * * *} \\
(.190)\end{array}$ & $\begin{array}{c}4.078^{* * * *} \\
(.647)\end{array}$ & $\begin{array}{c}-3.013^{* * * *} \\
(.898)\end{array}$ \\
\hline Host financial deepening & $\begin{array}{l}-.067 \\
(.088)\end{array}$ & $\begin{array}{c}-.041 * * * \\
(.005)\end{array}$ & $\begin{array}{c}-.139 * * * \\
(.027)\end{array}$ & $\begin{array}{c}-.075 * * \\
(.031)\end{array}$ \\
\hline Distance $\times$ Host financial deepening & $\begin{array}{l}.053 * * \\
(.023)\end{array}$ & $\begin{array}{c}.011 * * * \\
(.001)\end{array}$ & $\begin{array}{c}.002 \\
(.008)\end{array}$ & $\begin{array}{l}.029 * * \\
(.012)\end{array}$ \\
\hline Other variables & Yes & Yes & Yes & Yes \\
\hline Year dummies & Yes & Yes & Yes & Yes \\
\hline Country dummies & Yes & Yes & Yes & Yes \\
\hline Obs (no. of banks) & $1279(248)$ & $1279(248)$ & $1273(247)$ & $1276(248)$ \\
\hline Goodness of fit & .182 & .377 & .677 & .156 \\
\hline
\end{tabular}

Note: The numbers in parentheses denote errors of the coefficients. $* * * 1 \%, * * 5 \%$ and $* 10 \%$.

Table 8. Estimation results on the effects of financial crisis on distance constraints

\begin{tabular}{|c|c|c|c|c|}
\hline \multicolumn{5}{|l|}{ Dependent variables } \\
\hline & $\begin{array}{c}\text { Loan growth } \\
\text { rate }\end{array}$ & $\begin{array}{c}\text { Net interest } \\
\text { margin }\end{array}$ & $\begin{array}{l}\text { Share of other } \\
\text { earning assets }\end{array}$ & ROE \\
\hline Distance & $\begin{array}{c}-4.782 * * * \\
(1.156)\end{array}$ & $\begin{array}{c}-.500 * * * \\
(.115)\end{array}$ & $\begin{array}{c}2.152 * * * \\
(.506)\end{array}$ & $\begin{array}{c}-1.311 * * \\
(.570)\end{array}$ \\
\hline Dummy (financial crisis) & $\begin{array}{c}.978 \\
(2.258)\end{array}$ & $\begin{array}{l}.311 * * \\
(.151)\end{array}$ & $\begin{array}{c}-2.772 * * * \\
(.921)\end{array}$ & $\begin{array}{c}.684 \\
(1.084)\end{array}$ \\
\hline Distance $\times$ Dummy (financial crisis) & $\begin{array}{l}-2.339^{*} \\
(1.385)\end{array}$ & $\begin{array}{c}-.255 * * * \\
(.091)\end{array}$ & $\begin{array}{l}-.500 \\
(.504)\end{array}$ & $\begin{array}{l}.562 \\
(.736)\end{array}$ \\
\hline Other variables & Yes & Yes & Yes & Yes \\
\hline Year dummies & Yes & Yes & Yes & Yes \\
\hline Country dummies & Yes & Yes & Yes & Yes \\
\hline Obs (no. of banks) & $1307(254)$ & $1307(254)$ & $1301(253)$ & $1304(254)$ \\
\hline Goodness of fit & .178 & .360 & .690 & .147 \\
\hline
\end{tabular}

Note: The numbers in parentheses denote errors of the coefficients. $* * * 1 \%, * * 5 \%$ and $* 10 \%$ 
Table 9. Estimation results on the effects of stock market development on distance constraints

\begin{tabular}{|c|c|c|c|c|}
\hline \multicolumn{5}{|l|}{ Dependent variables } \\
\hline & $\begin{array}{l}\text { Loan growth } \\
\text { rate }\end{array}$ & $\begin{array}{l}\text { Net interest } \\
\text { margin }\end{array}$ & $\begin{array}{l}\text { Share of other } \\
\text { earning assets }\end{array}$ & ROE \\
\hline \multicolumn{5}{|c|}{ Panel A: Number of publicly listed companies } \\
\hline Distance & $\begin{array}{l}-9.276 * * * \\
(1.093)\end{array}$ & $\begin{array}{c}-.400 * * * \\
(.135)\end{array}$ & $\begin{array}{l}4.324 * * * \\
(.483)\end{array}$ & $\begin{array}{l}-1.643 * * \\
(.729)\end{array}$ \\
\hline Number of listed companies & $\begin{array}{c}.384 \\
(3.728)\end{array}$ & $\begin{array}{l}-.129 \\
(.278)\end{array}$ & $\begin{array}{l}-4.759 * * \\
(2.039)\end{array}$ & $\begin{array}{l}-3.349 \\
(2.097)\end{array}$ \\
\hline $\begin{array}{l}\text { Distance } \times \text { Number of listed } \\
\text { companies }\end{array}$ & $\begin{array}{l}3.294^{*} \\
(1.956)\end{array}$ & $\begin{array}{l}.634 * * * \\
(.171)\end{array}$ & $\begin{array}{c}-2.864 * * * \\
(1.087)\end{array}$ & $\begin{array}{l}1.964^{*} \\
(1.190)\end{array}$ \\
\hline Other variables & Yes & Yes & Yes & Yes \\
\hline Year dummies & Yes & Yes & Yes & Yes \\
\hline Country dummies & Yes & Yes & Yes & Yes \\
\hline Obs (no. of banks) & $1285(250)$ & $1285(250)$ & $1279(249)$ & $1282(250)$ \\
\hline Goodness of fit & .158 & .360 & .680 & .144 \\
\hline \multicolumn{5}{|c|}{ Panel B: Stock market capitalization } \\
\hline Distance & $\begin{array}{l}-8.371 * * * \\
(1.109)\end{array}$ & $\begin{array}{c}-.402 * * * \\
(.134)\end{array}$ & $\begin{array}{l}3.380 * * * \\
(.557)\end{array}$ & $\begin{array}{c}-1.485^{* *} \\
(.633)\end{array}$ \\
\hline Stock market capitalization & $\begin{array}{c}-.088 * * * \\
(.019)\end{array}$ & $\begin{array}{c}-.007 * * \\
(.003)\end{array}$ & $\begin{array}{c}-.040 * * \\
(.015)\end{array}$ & $\begin{array}{l}-.003 \\
(.012)\end{array}$ \\
\hline $\begin{array}{l}\text { Distance } \times \text { Stock market } \\
\text { capitalization }\end{array}$ & $\begin{array}{l}.026 * * * \\
(.010)\end{array}$ & $\begin{array}{l}.003 * * * \\
(.001)\end{array}$ & $\begin{array}{l}.007 \\
(.005)\end{array}$ & $\begin{array}{l}.007 \\
(.004)\end{array}$ \\
\hline Other variables & Yes & Yes & Yes & Yes \\
\hline Year dummies & Yes & Yes & Yes & Yes \\
\hline Country dummies & Yes & Yes & Yes & Yes \\
\hline Obs (no. of banks) & $1267(246)$ & $1267(246)$ & $1261(245)$ & $1264(246)$ \\
\hline Goodness of fit & .164 & .354 & .678 & .110 \\
\hline \multicolumn{5}{|c|}{ Panel C: Stock market turnover rate } \\
\hline Distance & $\begin{array}{l}-8.857 * * * \\
(1.325)\end{array}$ & $\begin{array}{l}-.423 * * * \\
(.083)\end{array}$ & $\begin{array}{l}1.450^{* * * *} \\
(.568)\end{array}$ & $\begin{array}{c}-1.462 * * \\
(.645)\end{array}$ \\
\hline Stock market turnover rate & $\begin{array}{l}.028 \\
(.019)\end{array}$ & $\begin{array}{l}-.001 \\
(.001)\end{array}$ & $\begin{array}{l}-.010 \\
(.006)\end{array}$ & $\begin{array}{l}.011 \\
(.009)\end{array}$ \\
\hline $\begin{array}{l}\text { Distance } \times \text { Stock market turnover } \\
\text { rate }\end{array}$ & $\begin{array}{l}.036 * * \\
(.016)\end{array}$ & $\begin{array}{l}.000 \\
(.001)\end{array}$ & $\begin{array}{c}-.011 * * \\
(.005)\end{array}$ & $\begin{array}{c}.007 \\
(.006)\end{array}$ \\
\hline Other variables & Yes & Yes & Yes & Yes \\
\hline Year dummies & Yes & Yes & Yes & Yes \\
\hline Country dummies & Yes & Yes & Yes & Yes \\
\hline Obs (no. of banks) & $1273(248)$ & $1273(248)$ & $1267(247)$ & $1270(248)$ \\
\hline Goodness of fit & .164 & .413 & .689 & .130 \\
\hline
\end{tabular}

Note: The numbers in parentheses denote errors of the coefficients. $* * * 1 \%$, ** 5\% and $* 10 \%$. 
Table 10. Estimation results on the effects of concentration level on distance constraints

\begin{tabular}{|c|c|c|c|c|}
\hline \multicolumn{5}{|l|}{ Dependent variables } \\
\hline & $\begin{array}{l}\text { Loan growth } \\
\text { rate }\end{array}$ & $\begin{array}{l}\text { Net interest } \\
\text { margin }\end{array}$ & $\begin{array}{l}\text { Share of other } \\
\text { earning assets }\end{array}$ & ROE \\
\hline Distance & $\begin{array}{c}-13.518^{* * * *} \\
(3.199)\end{array}$ & $\begin{array}{c}-1.525^{* * * *} \\
(.243)\end{array}$ & $\begin{array}{c}.533^{* * * *} \\
(1.367)\end{array}$ & $\begin{array}{l}-3.247^{*} \\
(1.679)\end{array}$ \\
\hline Concentration & $\begin{array}{l}-.088 \\
(.084)\end{array}$ & $\begin{array}{l}-.001 \\
(.006)\end{array}$ & $\begin{array}{l}-.012 \\
(.041)\end{array}$ & $\begin{array}{c}-.128 * * * \\
(.044)\end{array}$ \\
\hline Distance $\times$ Concentration & $\begin{array}{l}.113 * * \\
(.051)\end{array}$ & $\begin{array}{c}.014 * * * \\
(.003)\end{array}$ & $\begin{array}{l}-.047 * * \\
(.022)\end{array}$ & $\begin{array}{l}.024 \\
(.027)\end{array}$ \\
\hline Other variables & Yes & Yes & Yes & Yes \\
\hline Year dummies & Yes & Yes & Yes & Yes \\
\hline Country dummies & Yes & Yes & Yes & Yes \\
\hline Obs (no. of banks) & $1289(252)$ & $1289(252)$ & $1283(251)$ & $1286(252)$ \\
\hline Goodness of fit & .175 & .377 & .693 & .147 \\
\hline
\end{tabular}

Note: The numbers in parentheses denote errors of the coefficients. $* * * 1 \%, * * 5 \%$ and $* 10 \%$.

Table 11. Estimation results on the effects of subsidiary hierarchy on distance constraints

\begin{tabular}{|c|c|c|c|c|}
\hline \multicolumn{5}{|l|}{ Dependent variables } \\
\hline & $\begin{array}{c}\text { Loan growth } \\
\text { rate }\end{array}$ & $\begin{array}{c}\text { Net interest } \\
\text { margin }\end{array}$ & $\begin{array}{l}\text { Share of other } \\
\text { earning assets }\end{array}$ & ROE \\
\hline Distance & $\begin{array}{c}-5.356^{* * * *} \\
(1.425)\end{array}$ & $\begin{array}{c}-.489 * * * * \\
(.121)\end{array}$ & $\begin{array}{c}2.470^{* * *} \\
(.516)\end{array}$ & $\begin{array}{c}-1.066^{*} \\
(.648)\end{array}$ \\
\hline Hierarchy & $\begin{array}{l}.566^{*} \\
(.338)\end{array}$ & $\begin{array}{l}-.048^{*} \\
(.024)\end{array}$ & $\begin{array}{c}.319^{* * * *} \\
(.110)\end{array}$ & $\begin{array}{c}.416^{* * * *} \\
(.150)\end{array}$ \\
\hline Distance $\times$ Hierarchy & $\begin{array}{l}.550 * * \\
(.268)\end{array}$ & $\begin{array}{l}.035^{*} \\
(.018)\end{array}$ & $\begin{array}{c}-.199 * * * \\
(.075)\end{array}$ & $\begin{array}{l}.249 * * \\
(.099)\end{array}$ \\
\hline Other variables & Yes & Yes & Yes & Yes \\
\hline Year dummies & Yes & Yes & Yes & Yes \\
\hline Country dummies & Yes & Yes & Yes & Yes \\
\hline Obs (no. of banks) & $1307(254)$ & $1307(254)$ & $1301(253)$ & $1304(254)$ \\
\hline Goodness of fit & .187 & .362 & .690 & .151 \\
\hline
\end{tabular}

Note: The numbers in parentheses denote errors of the coefficients. $* * * 1 \%, * * 5 \%$ and $* 10 \%$. 
Table 12. Robustness Tests

\begin{tabular}{|c|c|c|c|c|}
\hline \multicolumn{5}{|l|}{ Dependent variables } \\
\hline & $\begin{array}{l}\text { Loan growth } \\
\text { rate }\end{array}$ & $\begin{array}{l}\text { Net interest } \\
\text { margin }\end{array}$ & $\begin{array}{l}\text { Share of other } \\
\text { earning assets }\end{array}$ & ROE \\
\hline Distance & $\begin{array}{l}-31.808 * * * \\
(6.223)\end{array}$ & $\begin{array}{l}-1.470 * * * \\
(.462)\end{array}$ & $\begin{array}{c}5.466 * * * \\
(1.804)\end{array}$ & $\begin{array}{c}-10.471 * * * \\
(2.581)\end{array}$ \\
\hline Dummy (M\&A) & $\begin{array}{c}7.352 * * * \\
(2.712)\end{array}$ & $\begin{array}{c}.627 * * * * \\
(.189)\end{array}$ & & \\
\hline Distance $\times$ Dummy $(\mathrm{M} \& \mathrm{~A})$ & $\begin{array}{c}-.642 \\
(1.764)\end{array}$ & $\begin{array}{l}-.227 \\
(.159)\end{array}$ & & \\
\hline History & $\begin{array}{c}-5.121 * * * \\
(1.839)\end{array}$ & $\begin{array}{l}-.181 \\
(.148)\end{array}$ & $\begin{array}{c}1.189^{* * *} \\
(.501)\end{array}$ & \\
\hline Distance $\times$ History & $\begin{array}{c}3.323 * * * \\
(1.013)\end{array}$ & $\begin{array}{l}.267 * * * * \\
(.087)\end{array}$ & $\begin{array}{l}-.691 * * \\
(.280)\end{array}$ & \\
\hline Dummy (information institutes) & $\begin{array}{l}-4.516 \\
(3.004)\end{array}$ & $\begin{array}{l}-.197 \\
(.140)\end{array}$ & & \\
\hline $\begin{array}{l}\text { Distance } \times \text { Dummy (information } \\
\text { institutes) }\end{array}$ & $\begin{array}{l}4.617 * \\
(2.542)\end{array}$ & $\begin{array}{l}.194 * \\
(.116)\end{array}$ & & \\
\hline Dummy (same language) & $\begin{array}{c}-20.521 * * \\
(10.121)\end{array}$ & & $\begin{array}{l}11.700^{* * * *} \\
(3.545)\end{array}$ & \\
\hline Distance $\times$ Dummy (same language) & $\begin{array}{c}11.736 * * \\
(4.768)\end{array}$ & & $\begin{array}{c}-4.218 * * \\
(1.652)\end{array}$ & \\
\hline Dummy (same region) & & $\begin{array}{l}-.371 \\
(.558)\end{array}$ & & $\begin{array}{l}-14.025^{* * *} \\
\quad(5.205)\end{array}$ \\
\hline Distance $\times$ Dummy (same region) & & $\begin{array}{l}.909 * * * * \\
(.330)\end{array}$ & & $\begin{array}{c}6.252^{* *} \\
(2.626)\end{array}$ \\
\hline Host financial deepening & $\begin{array}{c}-.258 * * * \\
(.090)\end{array}$ & $\begin{array}{c}-.052 * * * \\
(.005)\end{array}$ & & $\begin{array}{l}-.044 \\
(.035)\end{array}$ \\
\hline Distance $\times$ Host financial deepening & $\begin{array}{c}.138 * * * \\
(.049)\end{array}$ & $\begin{array}{l}.012 * * * \\
(.003)\end{array}$ & & $\begin{array}{c}.083^{* * * *} \\
(.017)\end{array}$ \\
\hline Dummy (financial crisis) & $\begin{array}{l}.157 \\
(2.942)\end{array}$ & $\begin{array}{l}.754 * * * \\
(.151)\end{array}$ & & \\
\hline Distance $\times$ Dummy (financial crisis) & $\begin{array}{c}-.529 \\
(1.716)\end{array}$ & $\begin{array}{l}.045 \\
(.101)\end{array}$ & & \\
\hline Number of listed companies & $\begin{array}{l}.107 \\
(5.412)\end{array}$ & $\begin{array}{l}-.153 \\
(.286)\end{array}$ & $\begin{array}{c}.386 \\
(2.374)\end{array}$ & $\begin{array}{c}.106 \\
(2.318)\end{array}$ \\
\hline Distance $\times$ Number of listed companies & $\begin{array}{c}4.802 \\
(2.939)\end{array}$ & $\begin{array}{l}-.056 \\
(.236)\end{array}$ & $\begin{array}{c}2.579 \\
(1.614)\end{array}$ & $\begin{array}{l}2.550^{*} \\
(1.537)\end{array}$ \\
\hline Stock market capitalization & $\begin{array}{l}-.040 \\
(.048)\end{array}$ & $\begin{array}{l}.001 \\
(.003)\end{array}$ & & \\
\hline Distance $\times$ Stock market capitalization & $\begin{array}{l}-.042 \\
(.027)\end{array}$ & $\begin{array}{l}-.002 \\
(.002)\end{array}$ & & \\
\hline Stock market turnover rate & $\begin{array}{l}.021 \\
(.021)\end{array}$ & & $\begin{array}{l}-.010 \\
(.006)\end{array}$ & \\
\hline Distance $\times$ Stock market turnover rate & $\begin{array}{l}.029^{*} \\
(.017)\end{array}$ & & $\begin{array}{l}-.010 * \\
(.005)\end{array}$ & \\
\hline Concentration & $\begin{array}{l}.157 \\
(.137)\end{array}$ & $\begin{array}{l}-.005 \\
(.006)\end{array}$ & $\begin{array}{l}.043 \\
(.038)\end{array}$ & \\
\hline Distance $\times$ Concentration & $\begin{array}{l}.075 \\
(.074)\end{array}$ & $\begin{array}{l}-.003 \\
(.004)\end{array}$ & $\begin{array}{l}-.028 \\
(.024)\end{array}$ & \\
\hline Hierarchy & $\begin{array}{c}1.801^{* * * *} \\
(.456)\end{array}$ & $\begin{array}{l}.055 \\
(.032)\end{array}$ & $\begin{array}{l}.165 \\
(.146)\end{array}$ & $\begin{array}{c}.632^{* * * *} \\
(.175)\end{array}$ \\
\hline Distance $\times$ Hierarchy & $\begin{array}{c}.351 \\
(.324)\end{array}$ & $\begin{array}{l}-.033 \\
(.023)\end{array}$ & $\begin{array}{l}-.174 * \\
(.102)\end{array}$ & $\begin{array}{l}.279 * * \\
(.110)\end{array}$ \\
\hline Other variables & Yes & Yes & Yes & Yes \\
\hline
\end{tabular}


Year dummies

Country dummies

Observations (no. of banks)

Goodness of fit
Yes

Yes

1213 (235)

178
Yes

Yes

$1217(236)$

.382
Yes

Yes

$1236(242)$

.663
Yes

Yes

1263 (245)

.145

Note: The numbers in parentheses denote errors of the coefficients. *** $1 \%, * * 5 \%$ and $* 10 \%$. 
Table A1. Correlation coefficients among bank performance dimensions

\begin{tabular}{|c|c|c|c|c|}
\hline & Loan growth rate & Net interest margin & $\begin{array}{l}\text { Share of other } \\
\text { earning assets }\end{array}$ & ROE \\
\hline Loan growth rate & 1.000 & & & \\
\hline Net interest margin & $0.056 * * *$ & 1.000 & & \\
\hline Share of other earning assets & $-0.171 * * *$ & $-0.191 * * *$ & 1.000 & \\
\hline $\mathrm{ROE}$ & $0.088 * * *$ & $0.109 * * *$ & 0.004 & 1.000 \\
\hline
\end{tabular}

Note: $* * * 1 \%, * * 5 \%$, and $* 10 \%$

Table A2. Correlation coefficients among distance and subsidiary characteristics

\begin{tabular}{|c|c|c|c|c|c|}
\hline & Distance & Liquidity & Capitalization & Size & Riskiness \\
\hline Distance & 1.000 & & & & \\
\hline Liquidity & $-0.039 *$ & 1.000 & & & \\
\hline Capitalization & $0.061^{* * *}$ & 0.024 & 1.000 & & \\
\hline Size & $-0.282 * * *$ & $-0.107 * * *$ & $-0.173 * * *$ & 1.000 & \\
\hline Riskiness & -0.006 & -0.028 & 0.019 & -0.012 & 1.000 \\
\hline
\end{tabular}

Note: $* * * 1 \%, * * 5 \%$, and $* 10 \%$

Table A3. Correlation coefficients among distance and parent bank characteristics

\begin{tabular}{|c|c|c|c|c|}
\hline & Distance & Parent bank mass & Parent bank liquidity & $\begin{array}{c}\text { Parent bank } \\
\text { capitalization }\end{array}$ \\
\hline Distance & 1.000 & & & \\
\hline Parent bank mass & $0.497 * * *$ & 1.000 & & \\
\hline Parent bank liquidity & $-0.060 * * *$ & 0.024 & 1.000 & \\
\hline Parent bank capitalization & $0.056^{* * *}$ & $-0.188 * * *$ & $-0.141 * * *$ & 1.000 \\
\hline
\end{tabular}

Note: $* * * 1 \%, * * 5 \%$, and $* 10 \%$ 
Table A4. List of multinational banks and the distribution of foreign subsidiaries in emerging and developing economies

\begin{tabular}{|c|c|c|c|}
\hline & Multination bank & $\begin{array}{l}\text { Home } \\
\text { country }\end{array}$ & Host countries \\
\hline 1 & ABN Amro & NL & $\begin{array}{l}\text { PL, RO, HU, KZ, AR, BR, CL, CO, MX, MY, } \\
\text { PK, PH }\end{array}$ \\
\hline 2 & Allied Irish Banks plc & $\mathrm{IE}$ & PL \\
\hline 3 & Alpha Bank AE & GR & MK, RS, RO \\
\hline 4 & American Express & US & BR, CL, MX, UY \\
\hline 5 & Australia and New Zealand Banking Group & AU & ID \\
\hline 6 & Banca Intesa & IT & HR, BA, RU, RS, SK \\
\hline 7 & Banca Nazionale del Lavoro SpA - BNL & IT & $\mathrm{AR}, \mathrm{BR}, \mathrm{UY}$ \\
\hline 8 & Banco Bilbao Vizcaya Argentaria SA & ES & AR, CL, CO, MX, PY, PE, UY, VE \\
\hline 9 & Banco Bradesco SA & BR & $\mathrm{AR}$ \\
\hline 10 & Banco Comercial Portugues SA & PT & PL, TR \\
\hline 11 & Banco do Brasil S.A. & $\mathrm{BR}$ & CL, PA \\
\hline 12 & Banco Itau SA & $\mathrm{BR}$ & $\mathrm{AR}$ \\
\hline 13 & Bank Austria Creditanstalt & AT & HR, SK, SI \\
\hline 14 & Bank of America & US & $\mathrm{BR}, \mathrm{MX}, \mathrm{HK}, \mathrm{ID}$ \\
\hline 15 & Bank of China & $\mathrm{CN}$ & RU, HK, MY \\
\hline 16 & Bank of Nova Scotia (The) - SCOTIABANK & $\mathrm{CA}$ & AR, CL, MX, PE, CR, JM, PA, SV, MY \\
\hline 17 & Bank of Tokyo - Mitsubishi UFJ & JP & PL, BR, MX, IN, MY \\
\hline 18 & Barclays Plc & GB & $\mathrm{EG}, \mathrm{ZA}$ \\
\hline 19 & Bayerische Hypo-und Vereinsbank AG & $\mathrm{DE}$ & BG, HR, CZ, HU, LV, PL, RO, HR, SK, SI \\
\hline 20 & Bayerische Landesbank & $\mathrm{DE}$ & $\mathrm{BG}, \mathrm{HU}$ \\
\hline 21 & BNP Paribas & FR & $\begin{array}{l}\text { BG, HU, PL, RU, UA, BR, MX, PE, PA, CN, } \\
\text { ID, EG }\end{array}$ \\
\hline 22 & Canadian Imperial Bank of Commerce CIBC & $\mathrm{CA}$ & JM, SG \\
\hline 23 & Citigroup & US & $\begin{array}{l}\text { CZ, HU, KZ, PL, RO, RU, SK, UA, BR, CL, } \\
\text { CO, MX, PY, PE, VE, HK, IN, KR, MY, SG, } \\
\text { HN, PA, TT }\end{array}$ \\
\hline 24 & Commerzbank AG & $\mathrm{DE}$ & HU, PL, RU, ID \\
\hline 25 & Commonwealth Bank of Australia & $\mathrm{AU}$ & ID \\
\hline 26 & Credit Agricole & FR & $\begin{array}{l}\text { AM, CZ, HU, PL, RU, RS, SK, UA, AR, BR, } \\
\text { UY, TR, EG }\end{array}$ \\
\hline 27 & Credit Suisse & $\mathrm{CH}$ & RU, BR \\
\hline 28 & Creditanstalt & AT & $\mathrm{CZ}, \mathrm{HU}, \mathrm{PL}$ \\
\hline 29 & Danske Bank A/S & DK & PL, RU \\
\hline 30 & DBS Group Holdings Ltd & SG & HK, ID, PH, TH \\
\hline 31 & Deutsche Bank AG & $\mathrm{DE}$ & HU, PL, RU, AR, BR, CL, UY, MY \\
\hline 32 & Dexia & $\mathrm{BE}$ & RU, SK, TR \\
\hline 33 & DnB Nor ASA & NO & RU \\
\hline 34 & Dresdner Bank AG & $\mathrm{DE}$ & HR, CZ, RU, BR, CL, MX \\
\hline 35 & DZ Bank AG & $\mathrm{DE}$ & HU, PL \\
\hline 36 & Emporiki Bank of Greece SA & GR & $\mathrm{AL}, \mathrm{BG}, \mathrm{RO}$ \\
\hline 37 & Erste Group Bank AG & AT & HR, CZ, HU, RO, RS, SK \\
\hline \multicolumn{4}{|c|}{40} \\
\hline
\end{tabular}




\begin{tabular}{|c|c|c|c|}
\hline 38 & Fortis Bank & $\mathrm{BE}$ & PL, TR, HK \\
\hline 39 & GE Capital & US & $\mathrm{CZ}, \mathrm{HU}, \mathrm{PL}, \mathrm{BR}, \mathrm{MX}$ \\
\hline 40 & HSBC & GB & $\begin{array}{l}\text { AM, PL, RU, TR, AR, BR, CL, CO, MX, PE, } \\
\text { UY, KZ, MY, EG }\end{array}$ \\
\hline 41 & Hypo Alpe-Adria Bank & AT & BA, HR, RS, SI \\
\hline 42 & ING Bank NV & NL & PL, RU, UA, AR, CL, MX, PY, UY, IN, ID, SG \\
\hline 43 & JP Morgan Chase & US & BR, MX, VE, MY \\
\hline 44 & KBC Group & $\mathrm{BE}$ & CZ, HU, PL, RU, SK \\
\hline 45 & Kookmin Bank & $\mathrm{KR}$ & HK \\
\hline 46 & Lloyds TSB Bank PLC & GB & $\mathrm{AR}, \mathrm{BR}$ \\
\hline 47 & National Bank of Greece SA & GR & BG, MK, RO, RS, TR \\
\hline 48 & Norddeutsche Landesbank Girozentrale NORD/LB & $\mathrm{DE}$ & LV, LT, PL \\
\hline 49 & Nordea Bank AB & SE & PL, RU \\
\hline 50 & $\begin{array}{l}\text { Oversea-Chinese Banking Corporation Limited } \\
\text { OCBC }\end{array}$ & SG & ID, MY \\
\hline 51 & Piraeus Bank SA & GR & $\mathrm{AL}, \mathrm{BG}, \mathrm{RO}, \mathrm{RS}$ \\
\hline 52 & ProCredit Holding AG & $\mathrm{DE}$ & GE, MD, UA \\
\hline 53 & Rabobank Nederland & NL & PL, BR, IN, ID, SG \\
\hline 54 & Raiffeisen Zentralbank Oesterreich AG - RZB & AT & $\begin{array}{l}\text { AL, BY, BA, BG, HR, CZ, HU, PL, RO, RU, } \\
\text { RS, SK, SI, UA }\end{array}$ \\
\hline 55 & Resona Bank Ltd & JP & ID \\
\hline 56 & Sampo Bank Plc & FI & EE, LV, LT \\
\hline 57 & Sanpaolo IMI & IT & $\mathrm{HU}, \mathrm{RO}, \mathrm{SI}$ \\
\hline 58 & Santander Central Hispano & ES & AR, BR, CL, CO, MX, PE, UY, VE, PA, PH \\
\hline 59 & Skandinaviska Enskilda Banken & SE & EE, LV, LT, UA \\
\hline 60 & Societe Generale & FR & $\begin{array}{l}\text { BG, HR, CZ, PL, RO, RU, RS, SI, AR, BR, MX, } \\
\text { ID, EG }\end{array}$ \\
\hline 61 & Standard Chartered Bank & GB & $\mathrm{CO}, \mathrm{PE}, \mathrm{HK}, \mathrm{KR}, \mathrm{MY}, \mathrm{TH}$ \\
\hline 62 & Sumitomo Mitsui Banking Corporation & JP & BR, ID \\
\hline 63 & Svenska Handelsbanken & SE & RU \\
\hline 64 & Swedbank AB & SE & EE, LV, LT, RU \\
\hline 65 & UBS & $\mathrm{CH}$ & BR \\
\hline 66 & UniCredit SpA & IT & BA, BG, CZ, HR, PL, RO, RU, SK, UA, TR \\
\hline 67 & Veneto Banca Holding scpa & IT & $\mathrm{HR}, \mathrm{MD}$ \\
\hline 68 & Volksbank & AT & HR, RO, RS, SK \\
\hline 69 & West LB & DE & HU, PL, RU, BR \\
\hline
\end{tabular}

Notes: $\mathrm{AL}=$ Albania, $\mathrm{AM}=$ Armenia, $\mathrm{AR}=$ Argentina, $\mathrm{AT}=$ Austria, $\mathrm{AU}=$ Australia, $\mathrm{BA}=\mathrm{B}$ osnia \& Herzegovina, $\mathrm{BE}=\mathrm{Belgium}, \mathrm{BR}=\mathrm{Brazil}$, $\mathrm{BG}=$ Bulgaria, $\mathrm{BY}=$ Belarus, $\mathrm{CA}=\mathrm{Canada}, \mathrm{CH}=$ Switzerland, $\mathrm{CL}=$ Chile, $\mathrm{CN}=\mathrm{China}, \mathrm{CO}=$ Colombia, $\mathrm{CR}=\mathrm{Costa} \mathrm{Rica}, \mathrm{CZ}=\mathrm{Czech}$, $\mathrm{DE}=$ Germany, DK=Denmark, EE=Estonia, EG=Egypt, ES=Spain, FI=Finland, FR=France, GB=UK, GE=Georgia, GR=Greece, HK=Hong Kong, HN=Honduras, HR=Croatia, HU=Hungary, ID=Indonesia, IE=Ireland, IN=India, IT=Italy, JM=Jamaica, JP=Japan, KR=Korea, $\mathrm{KZ}=$ Kazahkstan, LT=Lithuania, LV=Latvia, MD=Moldova, MK=Macedonia, MX=Mexico, MY=Malaysia, NL=Netherland, NO=Norway, $\mathrm{PA}=$ Panama, $\mathrm{PE}=\mathrm{Peru}, \mathrm{PH}=$ Philippines, $\mathrm{PK}=$ Pakistan, $\mathrm{PL}=$ Poland, $\mathrm{PT}=$ Portugal, $\mathrm{PY}=$ Paraguay, $\mathrm{RO}=$ Romania, $\mathrm{RS}=\mathrm{Serbia}, \mathrm{RU}=\mathrm{Russia}$, $\mathrm{SE}=$ Sweden, $\mathrm{SG}=$ Singapore, SK=Slovakia, SI=Slovenia, SV=El Salvador, TH= Thailand, TR=Turkey, TT=Trinidad \&Tobago, UA=Ukraine, US=United States, UY=Uruguay, VE=Venezuela, ZA=South Africa 


\section{Notes}

\footnotetext{
${ }^{1}$ Soft information means the information that cannot be directly verified by anyone except the agent who produces it. As opposed to "hard" information, which can be credibly verified by documents or other evidence, "soft" information cannot be unambiguously documented and passed on from loan officers to their superiors.

${ }^{2}$ Mian (2006) and Claessens and van Horsen (2009) only use dummies to measure the distance between host and home markets.

${ }^{3}$ The effect of parent banks on the behaviors of subsidiaries is studied in the "internal capital market" literature, which argues that the financial strength in parent banks would affect the availability of resources from the parent to the subsidiaries. Related works include Gilbert (1991), Houston et al. (1997), Houston and James (1998), Campello (2002), Holod and Peek (2006), Ashcraft (2008) and De Haas and van Lelyveld (2009).

${ }^{4}$ Related research how foreign subsidiaries may be affects by factors in their home countries can be seen in Peek and Rosengren (2000), Goldberger (2005) and some others.

53 out of 69 multinational banks in our sample are listed in the largest 100 banks in the world as of 2005 (in terms of the book value of equity capital). See The Banker, Vol. 155, No. 953.

${ }^{6}$ Branches are not included in our dataset.

7 The ratio of a subsidiary's total assets to the conglomerate's total assets is around $1 \%$ on average and the median value is even much lower (only $0.2 \%$ ). See Table 1.

${ }^{8}$ The single item of the tested factor would be interpreted as it may affect banks' behavior via other unidentified channels.

${ }^{9}$ Recently, the role of legal system in determining the development of financial system has received an intensive attention (see La Porta et al. (1998), Beck et al. (2003) etc.)

${ }^{10}$ The official languages in our sampled countries include English, Spanish, Italian, Portuguese, French, Chinese and others. In total 43 different languages. The legal origins are categorized into French, German, English, Scandinavian and socialist legal systems, following La Porta et al. (1998) and Djankov et al. (2007). Regions are grouped into North America, South America, Central America, Europe, East Asia, South Asia, Southeast Asia, Mideast, Central Asia and Russia, Australia and New Zealand, and Africa.

${ }^{11}$ Our results are consistent with Claessens and van Horen (2009), who also find that the same language and region improve the performance of foreign banks but the same legal system does not.
} 